\title{
Exploring water cycle dynamics by sampling multiple stable water isotope pools in a developed landscape in Germany
}

\author{
Natalie Orlowski ${ }^{1,2}$, Philipp Kraft ${ }^{1}$, Jakob Pferdmenges ${ }^{1}$, and Lutz Breuer ${ }^{1,3}$ \\ ${ }^{1}$ Institute for Landscape Ecology and Resources Management (ILR), Research Centre for BioSystems, Land Use and \\ Nutrition (iFZ), Justus Liebig University Gießen, Gießen, Germany \\ ${ }^{2}$ Global Institute for Water Security, University of Saskatchewan, Saskatoon, Canada \\ ${ }^{3}$ Centre for International Development and Environmental Research, Justus Liebig University Gießen, Gießen, Germany \\ Correspondence to: N. Orlowski (natalie.orlowski@umwelt.uni-giessen.de)
}

Received: 5 November 2014 - Published in Hydrol. Earth Syst. Sci. Discuss.: 6 February 2015

Revised: 27 July 2016 - Accepted: 16 August 2016 - Published: 20 September 2016

\begin{abstract}
A dual stable water isotope $\left(\delta^{2} \mathrm{H}\right.$ and $\left.\delta^{18} \mathrm{O}\right)$ study was conducted in the developed (managed) landscape of the Schwingbach catchment (Germany). The 2-year weekly to biweekly measurements of precipitation, stream, and groundwater isotopes revealed that surface and groundwater are isotopically disconnected from the annual precipitation cycle but showed bidirectional interactions between each other. Apparently, snowmelt played a fundamental role for groundwater recharge explaining the observed differences to precipitation $\delta$ values.

A spatially distributed snapshot sampling of soil water isotopes at two soil depths at 52 sampling points across different land uses (arable land, forest, and grassland) revealed that topsoil isotopic signatures were similar to the precipitation input signal. Preferential water flow paths occurred under forested soils, explaining the isotopic similarities between top- and subsoil isotopic signatures. Due to human-impacted agricultural land use (tilling and compression) of arable and grassland soils, water delivery to the deeper soil layers was reduced, resulting in significant different isotopic signatures. However, the land use influence became less pronounced with depth and soil water approached groundwater $\delta$ values. Seasonally tracing stable water isotopes through soil profiles showed that the influence of new percolating soil water decreased with depth as no remarkable seasonality in soil isotopic signatures was obvious at depths $>0.9 \mathrm{~m}$ and constant values were observed through space and time. Since classic isotope evaluation methods such as transfer-function-based mean transit time calculations did not provide a good fit between the observed and calculated data, we established a hy-
\end{abstract}

drological model to estimate spatially distributed groundwater ages and flow directions within the Vollnkirchener Bach subcatchment. Our model revealed that complex age dynamics exist within the subcatchment and that much of the runoff must has been stored for much longer than event water (average water age is 16 years). Tracing stable water isotopes through the water cycle in combination with our hydrological model was valuable for determining interactions between different water cycle components and unravelling age dynamics within the study area. This knowledge can further improve catchment-specific process understanding of developed, human-impacted landscapes.

\section{Introduction}

The application of stable water isotopes as natural tracers in combination with hydrodynamic methods has been proven to be a valuable tool for studying the origin and formation of recharged water as well as the interrelationship between surface water and groundwater (Blasch and Bryson, 2007), partitioning evaporation and transpiration (Wang and Yakir, 2000), and mixing processes between various water sources (Clark and Fritz, 1997c). Particularly in catchment hydrology, stable water isotopes play a major role since they can be utilized for hydrograph separations (Buttle, 2006), to calculate the mean transit time (McGuire and McDonnell, 2006), to investigate water flow paths (Barthold et al., 2011), or to improve hydrological model simulations (Windhorst et al., 2014). However, most of our current under- 
standing results from studies in forested catchments. Spatiotemporal studies of stream water in developed, agriculturally dominated, and managed catchments are less abundant. This is partly caused by damped stream water isotopic signatures excluding traditional hydrograph separations in lowrelief catchments (Klaus et al., 2015). Unlike the distinct watershed components found in steeper headwater counterparts, lowland areas often exhibit a complex groundwatersurface-water interaction (Klaus et al., 2015). Sklash and Farvolden (1979) showed that groundwater plays an important role as a generating factor for storm and snowmelt runoff processes. In many catchments, streamflow responds promptly to rainfall inputs but variations in passive tracers such as water isotopes are often strongly damped (Kirchner, 2003). This indicates that storm runoff in these catchments is dominated mostly by "old water" (Buttle, 1994; Neal and Rosier, 1990; Sklash, 1990). However, not all old water is the same (Kirchner, 2003). This catchment behaviour was described by Kirchner (2003) as the old-water paradox. Thus, there is evidence of complex age dynamics within catchments and much of the runoff is stored in the catchment for much longer than event water (Rinaldo et al., 2015). Still, some of the physical processes controlling the release of old water from catchments are poorly understood and roughly modelled, and the observed data do not suggest a common catchment behaviour (Botter et al., 2010). However, old-water paradox behaviour was observed in many catchments worldwide, but it may have the strongest effect in agriculturally managed catchments, where surprisingly only small changes in stream chemistry have been observed (Hrachowitz et al., 2016).

Moreover, almost all European river systems were already substantially modified by humans before river ecology research developed (Allan, 2004). Through changes in land use, land cover, irrigation, and draining, agriculture has substantially modified the water cycle in terms of both quality and quantity (Gordon et al., 2010) as well as hydrological functioning (Pierce et al., 2012). Hrachowitz et al. (2016) recently stated the need for a stronger linkage between catchment-scale hydrological and water quality communities. Further, McDonnell et al. (2007) concluded that we need to figure out a way to embed landscape heterogeneity or the consequence of the heterogeneity (i.e. of agriculturally dominated and managed catchments) into models as currentgeneration catchment-scale hydrological and water quality models are poorly linked (Hrachowitz et al., 2016).

One way to better understand catchment behaviour and the interaction among the various water sources (surface, subsurface, and groundwater) and their variation in space and time is a detailed knowledge about their isotopic composition. In principal, isotopic signatures of precipitation are altered by temperature, amount (or rainout), continental, altitudinal, and seasonal effects. Stream water isotopic signatures can reflect precipitation isotopic composition and, moreover, dependent on discharge variations, be affected by seasonally variable contributions of different water sources such as bidirectional water exchange with the groundwater body during baseflow or high event-water contributions during storm flow (Genereux and Hooper, 1998; Koeniger et al., 2009). Precipitation falling on vegetated areas is partly intercepted by plants and re-evaporated isotopically fractionated. The remaining throughfall infiltrates slower and can be affected by evaporation resulting in an enrichment of heavy isotopes, particularly in the upper soil layers (Gonfiantini et al., 1998; Kendall and Caldwell, 1998). In the soil, specific isotopic profiles develop, characterized by an evaporative layer near the surface. The isotopic enrichment decreases exponentially with depth, representing a balance between the upward convective flux and the downward diffusion of the evaporative signature (Barnes and Allison, 1988). In humid and semihumid areas, this exponential decrease is generally interrupted by the precipitation isotopic signal. Hence, the combination of the evaporation effect and the precipitation isotopic signature determine the isotope profile in the soil (Song et al., 2011). Once soil water reaches the saturated zone, this isotope information is finally transferred to the groundwater (Song et al., 2011). Soil water can therefore be seen as a link between precipitation and groundwater, and the dynamics of isotopic composition in soil water are indicative of the processes of precipitation infiltration, evaporation of soil water, and recharge to groundwater (Blasch and Bryson, 2007; Song et al., 2011).

We started our research with results obtained through an earlier study in the managed Schwingbach catchment that implied a high responsiveness of the system to precipitation inputs indicated by very fast rises in discharge and groundwater head levels (Orlowski et al., 2014). However, as there was only a negligible influence of the precipitation input signal on the stable water isotopic composition in streams, our initial data set showed evidence of complex age dynamics within the catchment. Nevertheless, a rapid flow response to a precipitation input may also be mistaken (as conceptualized in the vast majority of catchment-scale conceptual hydrological models) for the actual input signal already reaching the stream, while in reality it is the remainder of past input signals that have slowly travelled through the system (Hrachowitz et al., 2016). The observable hydrological response therefore acts on different timescales from the tracer response (Hrachowitz et al., 2016) as described by the celerity vs. velocity concept (McDonnell and Beven, 2014). The observed patterns in our catchment therefore inspired us to use a combined approach of hydrodynamic data analyses, stable water isotope investigations, and data-driven hydrological modelling to determine catchment dynamics (response times and groundwater age patterns) and unravel water flow paths on multiple spatial scales. This work should further improve our knowledge of hydrological flow paths in developed, human-impacted catchments. 
(c)

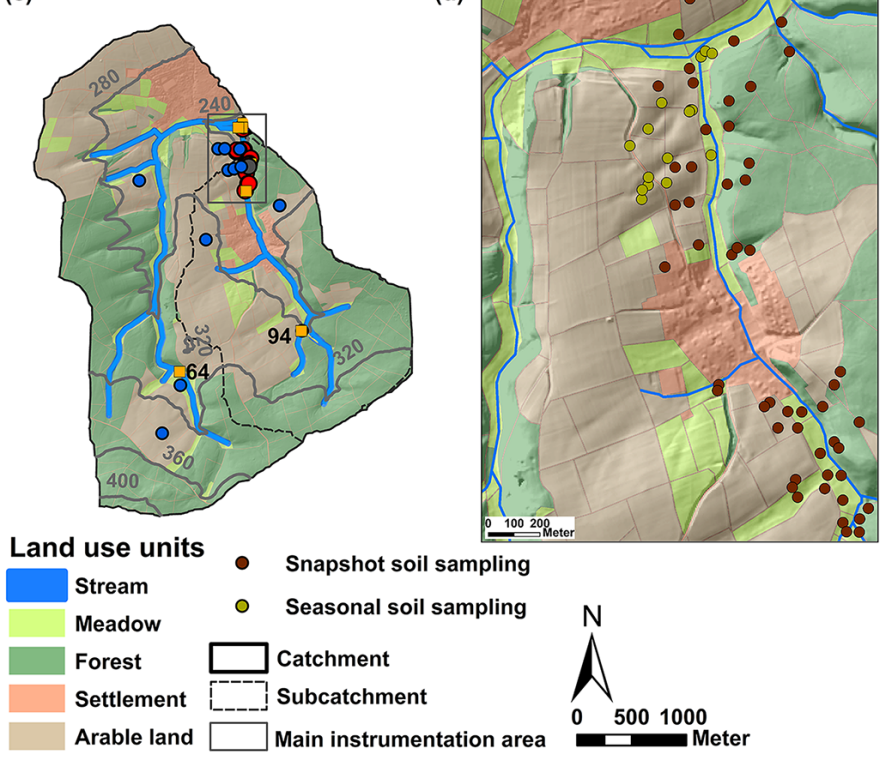

(e)

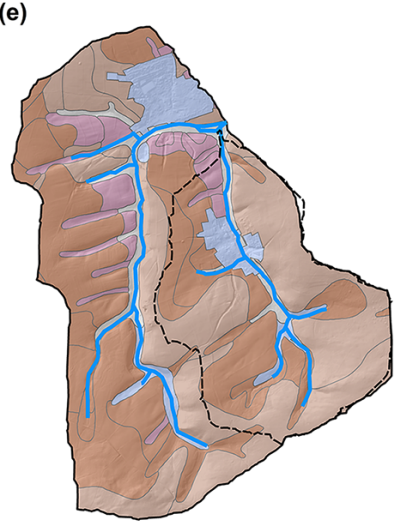

(f)

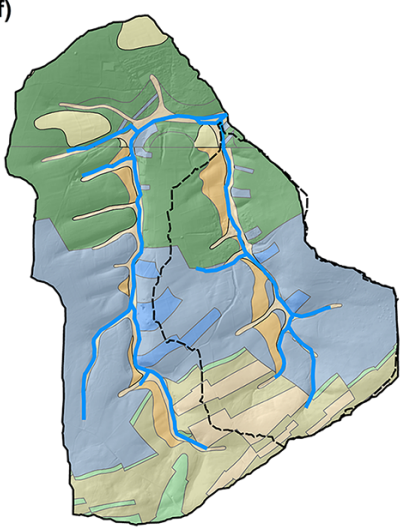

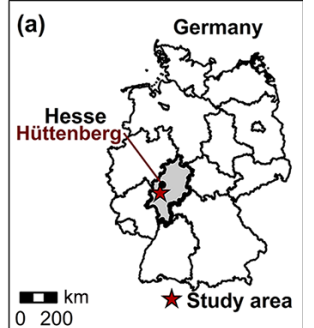

\section{0}
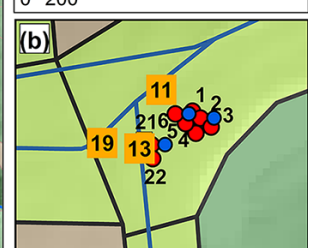

.
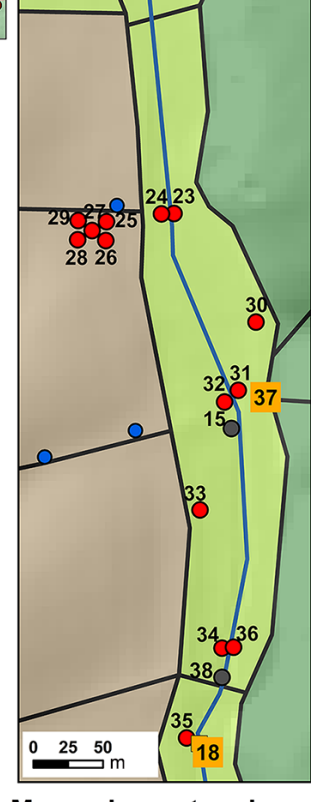

Measuring network

O Piezometer

$\square$ Stream water sampling

$\square$ Climate station (13)

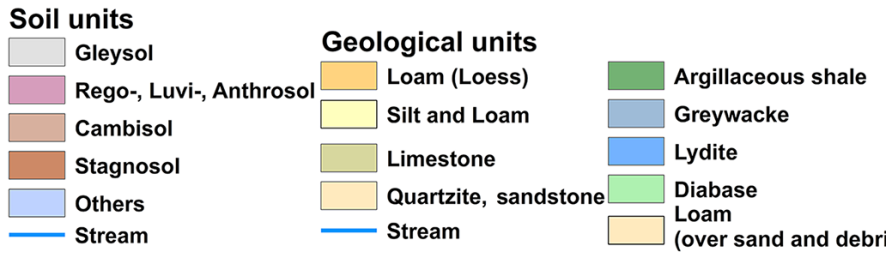

O Precipitation sampling

Drainage (15)

Combined sewer

overflow (38)

Figure 1. Maps show (a) the location of the Schwingbach catchment in Germany, (b) the main monitoring area, (c) the land use, elevation, and instrumentation, (d) the locations of the snapshot as well as the seasonal soil samplings, (e) soil types, and (f) geology of the Schwingbach catchment including the Vollnkirchener Bach subcatchment boundaries.

\section{Materials and methods}

\subsection{Study area}

The research was carried out in the Schwingbach catchment $\left(50^{\circ} 30^{\prime} 4.23^{\prime \prime} \mathrm{N}, 8^{\circ} 33^{\prime} 2.82^{\prime \prime} \mathrm{E}\right)$ (Germany) (Fig. 1a). The Schwingbach and its main tributary the Vollnkirchener Bach are low mountainous creeks and have an altitudinal difference of $50-100 \mathrm{~m}$ over a $5 \mathrm{~km}$ distance (Perry and Tay- lor, 2009) (Fig. 1c) with an altered physical structure of the stream system (channelled stream reaches, pipes, drainage systems, fishponds). The Schwingbach catchment $\left(9.6 \mathrm{~km}^{2}\right)$ ranges from $233-415 \mathrm{~m}$ a.s.l. with an average slope of $8.0 \%$. The Vollnkirchener Bach tributary is $4.7 \mathrm{~km}$ in length and drains a $3.7 \mathrm{~km}^{2}$ subcatchment area (Fig. 1c), with elevations from 235 to $351 \mathrm{~m}$ a.s.l. Almost $46 \%$ of the overall Schwingbach catchment is forested, which slightly exceeds agricultural land use (35\%) (Fig. 1c). Grassland (10\%) is mainly 
distributed along streams, and smaller meadow orchards are located around the villages.

The Schwingbach main catchment is underlain by argillaceous shale in the northern parts, serving as aquicludes. Greywacke zones with lydite in the central, as well as limestone, quartzite, and sandstone regions in the headwater area provide aquifers with large storage capacities (Fig. 1f). Loess covers Paleozoic bedrock at north- and east-bounded hillsides (Fig. 1f). Streambeds consists of sand and debris covered by loam and some larger rocks (Lauer et al., 2013). Many downstream sections of both creeks are framed by armour stones (Orlowski et al., 2014). The dominant soil types in the overall study area are Stagnosols (41\%) and mostly forested Cambisols (38\%). Stagnic Luvisols with thick loess layers, Regosol, Luvisols, and Anthrosols are found under agricultural use and Gleysols under grassland along the creeks.

The climate is classified as temperate with a mean annual temperature of $8.2^{\circ} \mathrm{C}$. An annual precipitation sum of $633 \mathrm{~mm}$ (for the hydrological year 1 November 2012 to 31 October 2013) was measured at the catchment's climate station (site 13, Fig. 1b). The year 2012 to 2013 was an average hydrometeorological year. For comparison, the climate station Gießen/Wettenberg ( $25 \mathrm{~km}$ north of the catchment) operated by the German Meteorological Service (DWD, 2014) records a mean annual temperature of $9.6^{\circ} \mathrm{C}$ and a mean annual precipitation sum of $666 \pm 103 \mathrm{~mm}$ for the period 1980-2010. Discharge peaks from December to April (measured by the use of RBC flumes with a maximum peak flow of $114 \mathrm{~L} \mathrm{~s}^{-1}$, Eijkelkamp Agrisearch Equipment, Giesbeek, NL), and low flows occur from July until November. Substantial snowmelt peaks were observed during December 2012 and February 2013. Furthermore, May 2013 was an exceptionally wet month characterized by discharge of 2$3 \mathrm{~mm}$ day $^{-1}$. A detailed description of runoff characteristics is given by Orlowski et al. (2014).

\subsection{Monitoring network and water isotope sampling}

The monitoring network consists of an automated climate station (site 13, Fig. 1b-c) (Campbell Scientific Inc., AQ5, UK; equipped with a CR1000 data logger), 3 tipping buckets, and 15 precipitation collectors, 6 stream water sampling points, and 22 piezometers (Fig. 1b-c). Precipitation data were corrected according to Xia (2006).

Two stream water sampling points (sites 13 and 18) in the Vollnkirchener Bach are installed with trapezium-shaped RBC flumes for gauging discharge (Eijkelkamp Agrisearch Equipment, Giesbeek, NL), and a V-notch weir is located at sampling point 64 . RBC flumes and V-notch weir are equipped with Mini-Divers ${ }^{\circledR}$ (Eigenbrodt Inc. \& Co. KG, Königsmoor, DE) for automatically recording water levels. Discharge at the remaining stream sampling points was manually measured applying the salt dilution method (WTW-cond340i, WTW, Weilheim, DE). The 22 piezome-

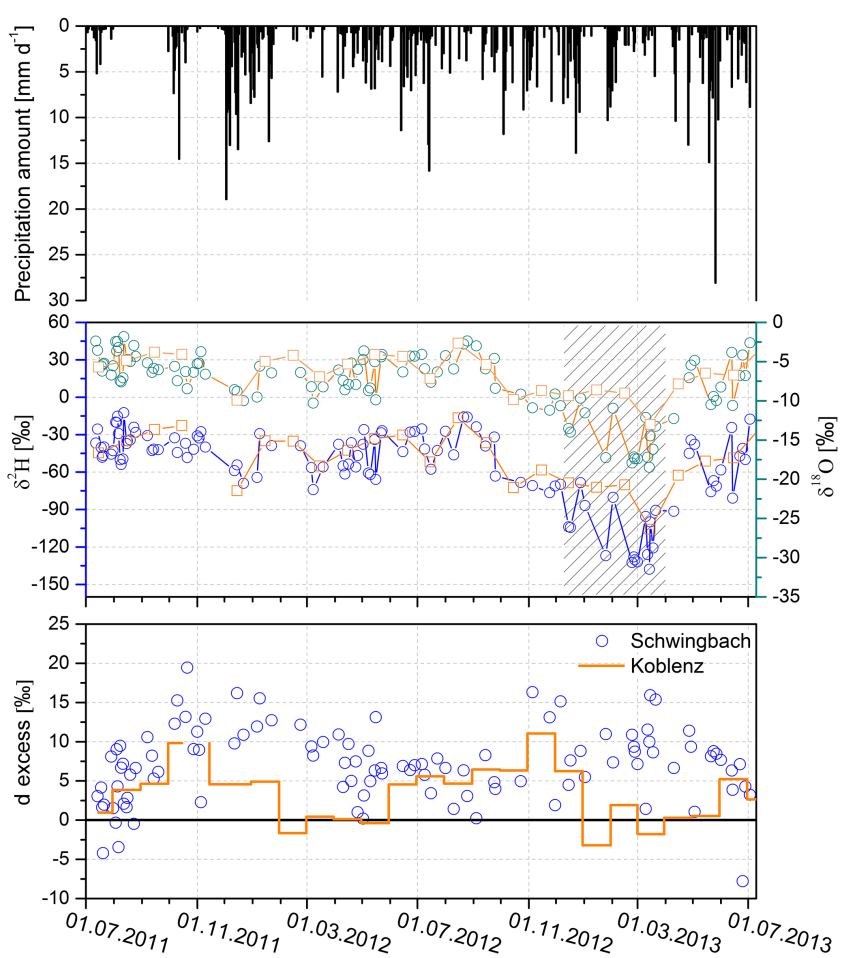

Figure 2. Temporal variation of precipitation amount, isotopic signatures $\left(\delta^{2} \mathrm{H}\right.$ and $\left.\delta^{18} \mathrm{O}\right)$ including snow samples (grey striped box) of the Schwingbach and GNIP station Koblenz, and d-excess values for the study area compared to monthly d-excess values (July 2011 to July 2013) of GNIP station Koblenz with reference d excess of GMWL ( $\mathrm{d}=10$; solid black line).

ters (Fig. 1b) are made from perforated PVC tubes sealed with bentonite at the upper part of the tube to prevent contamination by surface water. For monitoring shallow groundwater levels, either combined water level and temperature loggers (Odyssey Data Flow System, Christchurch, NZ) or Mini-Diver ${ }^{\circledR}$ water level loggers (Eigenbrodt Inc. \& Co. KG, Königsmoor, DE) are installed. The accuracy of Mini-Diver ${ }^{\circledR}$ is $\pm 5 \mathrm{~mm}$ and it is $\pm 1 \mathrm{~mm}$ for the Odyssey data logger. For calibration purposes, groundwater levels are additionally measured manually via an electric contact gauge.

Stable water isotope samples of rainfall and stream- and groundwater were taken from July 2011 to July 2013 at weekly intervals. In winter 2012-2013, snow core samples over the entire snow depth of $<0.15 \mathrm{~m}$ were collected in tightly sealed jars at the same sites as open rainfall was sampled. We sampled shortly after snowfall because sublimation, recrystallization, partial melting, rainfall on snow, and redistribution by wind can alter the isotopic composition (Clark and Fritz, 1997b). Samples were melted overnight following the method of Kendall and Caldwell (1998) and analysed for their isotopic composition. Open rainfall was collected in self-constructed samplers as in Windhorst et al. (2013). Grab samples of stream water were taken at six locations, 


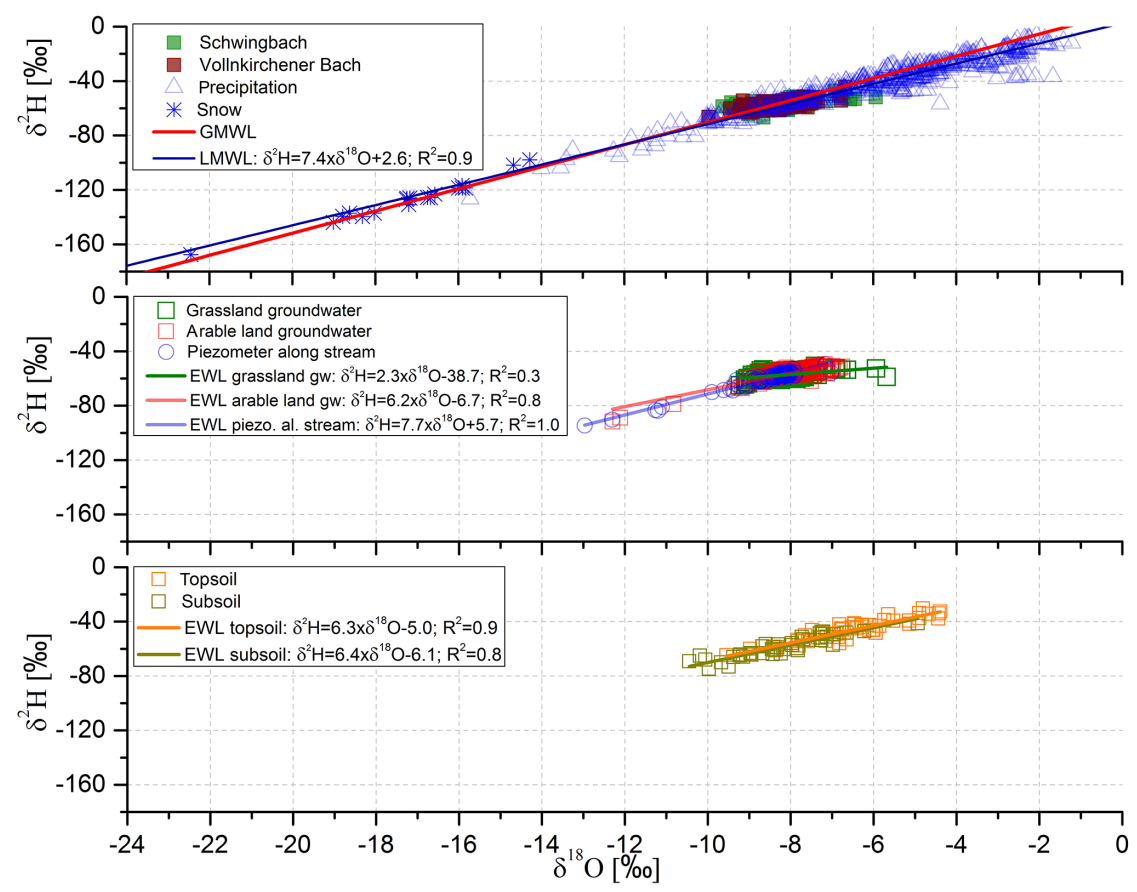

Figure 3. Local meteoric water line for the Schwingbach catchment (LMWL) in comparison to GMWL, including comparisons between precipitation, stream water, groundwater, and soil water isotopic signatures and the respective EWLs.

with three sampling points at each stream (Fig. 1b-c). Since spatial isotopic variations of groundwater among piezometers under the meadow were small, samples were collected at three out of eight sampling points under the meadow (sites 3,6 , and 21), five under the arable field (sites 25-29), and four next to the Vollnkirchener Bach (sites 24, 31, 32, and 35) (Fig. 1b). Additionally, a drainage pipe (site 15) located $\sim 226 \mathrm{~m}$ downstream of site 18 was sampled. According to IAEA standard procedures, all samples were filled and stored in $2 \mathrm{~mL}$ brown glass vials, sealed with a solid lid, and wrapped up with Parafilm ${ }^{\circledR}$.

\subsection{Isotopic soil sampling}

\subsubsection{Spatial variability}

In order to analyse the effect of small-scale characteristics such as distance to stream, topographic wetness index (TWI), and land use on soil isotopic signatures, we sampled a snapshot of 52 points evenly distributed over a $200 \mathrm{~m}$ grid around the Vollnkirchener Bach (Fig. 1d). Soil samples were taken on four consecutive rainless days (1 to 4 November 2011) at elevations of 235-294 ma.s.l. Sampling sites were selected via a stratified, GIS-based sampling plan (ArcGIS, Arc Map 10.2.1, Esri, California, USA), including three classes of TWIs (4.4-6.5; 6.5-7.7; 7.7-18.4), two different distances to the stream $(0-121$ and $121-250 \mathrm{~m})$, and three land uses (arable land, forest, and grassland), with each class containing the same number of sampling points. Samples were col-

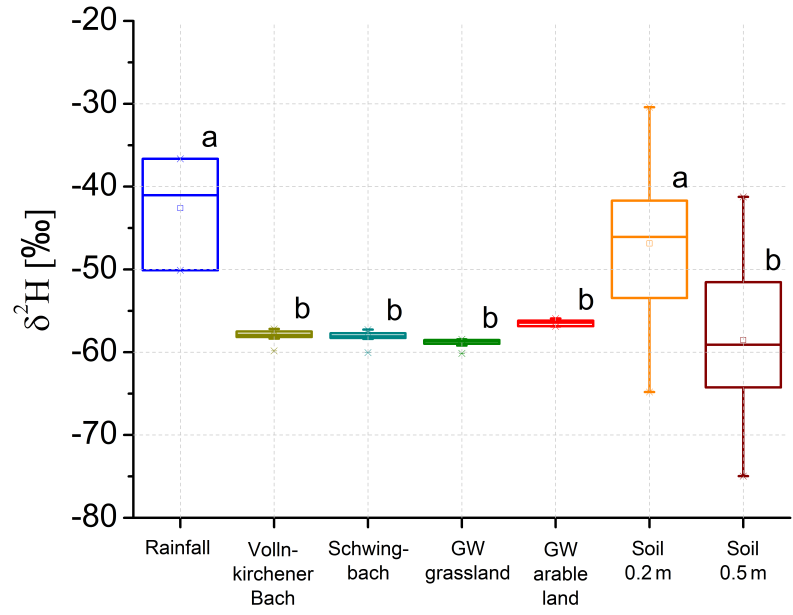

Figure 4. Box plots of $\delta^{2} \mathrm{H}$ values comparing precipitation, stream, groundwater, and soil isotopic composition at 0.2 and $0.5 \mathrm{~m}$ depth $(N=52$ per depth). Different letters indicate significant differences $(p \leq 0.05)$.

lected at depths of 0.2 and $0.5 \mathrm{~m}$. Gravimetric water content was measured according to DIN-ISO 11465 by drying soils for $24 \mathrm{~h}$ at $110^{\circ} \mathrm{C}$. Soil $\mathrm{pH}$ was analysed following DINISO 10390 on $1: 1$ soil-water mixture with a handheld $\mathrm{pH}$ meter (WTW cond340i, WTW Inc., DE). Bulk density was determined according to DIN-ISO 11272 and soil texture by finger testing. 

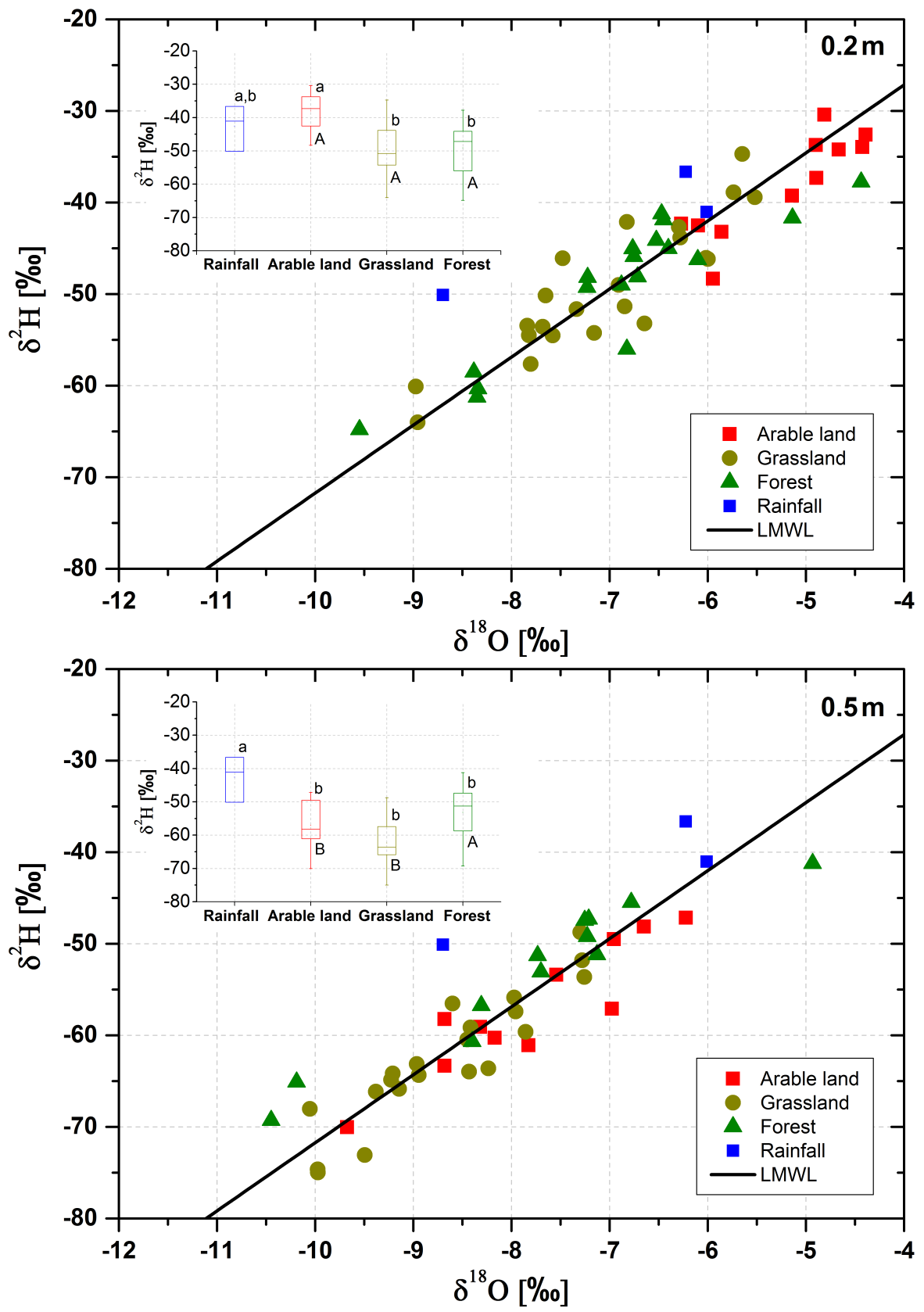

Figure 5. Dual isotope plot of soil water isotopic signatures at 0.2 and $0.5 \mathrm{~m}$ depth compared by land use including precipitation isotope data from 19, 21, and 28 October 2011. Insets: box plots comparing $\delta^{2} \mathrm{H}$ isotopic signatures between different land use units and precipitation (small letters) in top- and subsoil (capital letters). Different letters indicate significant differences $(p \leq 0.05)$.

\subsubsection{Seasonal isotope soil profiling and isotope analysis}

In order to trace the seasonal development of stable water isotopes from rainfall to groundwater, seven soil profiles were taken in the dry summer season (28 August 2011), seven in the wet winter period (28 March 2013), and two profiles in spring (24 April 2013) under different vegetation cover (arable land and grassland) (Fig. 1d). Soil was sampled from the soil surface to $2 \mathrm{~m}$ depth utilizing a hand auger (Eijkelkamp Agrisearch Equipment BV, Giesbeek, DE). More samples were collected near the soil surface since this area is known to have the greatest isotopic variability (Barnes and Allison, 1988).

Soil samples were stored in amber glass tubes, sealed with Parafilm ${ }^{\circledR}$, and kept frozen until water extraction. Soil water was extracted cryogenically with 180 min extraction duration, a vacuum threshold of $0.3 \mathrm{~Pa}$, and an extraction tem- 



Figure 6. Seasonal $\delta^{2} \mathrm{H}$ profiles of soil water (upper panels) and water content (lower panels) for winter (28 March 2013), summer (28 August 2011), and spring (24 April 2013). Error bars represent the natural isotopic variation of the replicates taken during each sampling campaign. For reference, mean groundwater (grey shaded) and mean seasonal precipitation $\delta^{2} \mathrm{H}$ values are shown (coloured arrows at the top).

perature of $90^{\circ} \mathrm{C}$ following Orlowski et al. (2013). Isotopic signatures of $\delta^{18} \mathrm{O}$ and $\delta^{2} \mathrm{H}$ were analysed via off-axis integrated cavity output spectroscopy (OA-ICOS) (DLT-100, Los Gatos Research Inc., Mountain View, USA). Within each isotope analysis three calibrated stable water isotope stan- dards of different water isotope ratios were included (Los Gatos Research (LGR) working standard number 1, 3, and 5; Los Gatos Research Inc., CA, US). After every fifth sample the LGR working standards are measured. For each sample, six sequential $900 \mu \mathrm{L}$ aliquots of a water sample are injected 


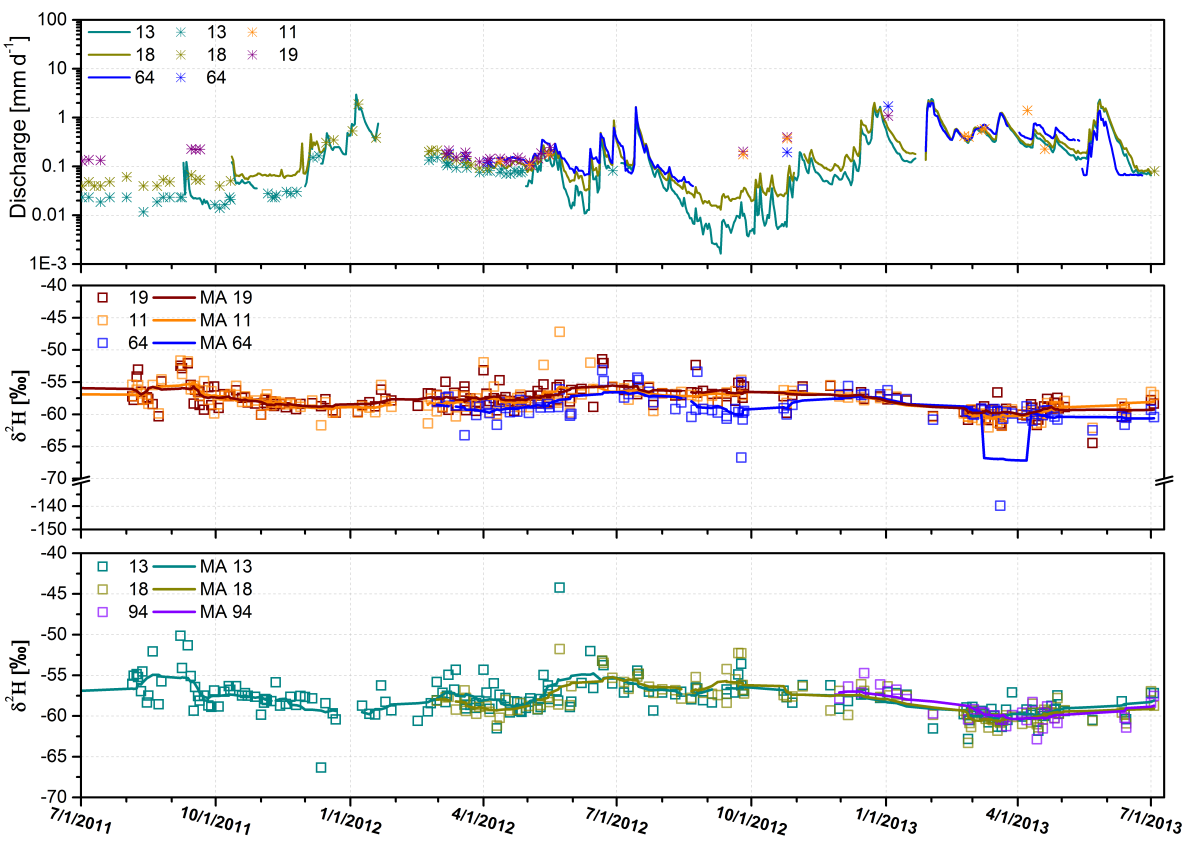

Figure 7. Mean daily discharge at the Vollnkirchener Bach $(13,18)$ and Schwingbach (site 11, 19, and 64) with automatically recorded data (solid lines) and manual discharge measurements (asterisks), temporal variation of $\delta^{2} \mathrm{H}$ of stream water in the Schwingbach (site 11, 19, and 64) and Vollnkirchener Bach (site 13, 18, and 94) including moving averages (MAs) for streamflow isotopes.

into the analyser. Then, the first three measurements are discarded. The remaining are averaged and corrected for per mil scale linearity following the IAEA laser spreadsheet template (Newman et al., 2009). Following this IAEA standard procedure allows for drift and memory corrections. Isotopic ratios are reported in per mil (\%o) relative to Vienna Standard Mean Ocean Water (VSMOW) (Craig, 1961b). The accuracy of analyses was $0.6 \%$ for $\delta^{2} \mathrm{H}$ and $0.2 \%$ for $\delta^{18} \mathrm{O}$ (LGR, 2013). Leaf water extracts typically contain a high fraction of organic contaminations, which might lead to spectral interferences when using isotope ratio infrared absorption spectroscopy, causing erroneous isotope values (Schultz et al., 2011). However, for soil water extracts there exists no need to check or correct such data (Schultz et al., 2011; Zhao et al., 2011).

\subsection{Mean transit time estimation}

To understand the connection between the different water cycle components in the Schwingbach catchment, mean transit times (MTTs) for both streams as well as from precipitation to groundwater were calculated using FlowPC (Maloszewski and Zuber, 2002). See Appendix A for details about the applied method.

\subsection{Model-based groundwater age dynamics}

To estimate the age dynamics of the groundwater body in the Vollnkirchener Bach subcatchment, a hydrological model was established on the basis of the conceptual model pre- sented by Orlowski et al. (2014) and the isotopic measurements presented here. Appendix B outlines the modelling concept, model set-up, and its parameterization.

\subsection{Statistical analyses}

For statistical analyses, we used IBM SPSS Statistics (Version 22, SPSS Inc., Chicago, IL, US) and R (version Rx64 3.2.2). The R package igraph was utilized for plotting (Csardi and Nepusz, 2006). In order to study temporal and spatial variations in meteoric and groundwater, isotope data were tested for normal distribution. Subsequently, $t$ tests or multivariate analyses of variance (MANOVAs) were applied and Tukey's honest significant difference (HSD) tests were run to determine which groups were significantly different $(p \leq 0.05)$. Event mean values of isotopes in precipitation, stream, and groundwater were calculated when no spatial variation was observed. Regression analyses were run to determine the effect of small-scale characteristics such as distance to stream, TWI, and land use on soil isotopic signatures.

We used a topology inference network map (Kolaczyk, 2014 ) in combination with a principal component analysis to show $\delta^{18} \mathrm{O}$ isotope relationships between surface and groundwater sampling points. To explore the sensitivity of missing data, we used both the complete isotope time series and randomly selected $80 \%$ of the whole data sets. Overall, the cluster relationships of the surface and groundwater sampling points are largely similar for both entire and subsets of 
Table 1. Descriptive statistics of $\delta^{2} \mathrm{H}, \delta^{18} \mathrm{O}$, and d-excess values for precipitation, stream, and groundwater over the 2-year observation period including all sampling points.

\begin{tabular}{|c|c|c|c|c|c|c|c|c|}
\hline \multirow[t]{2}{*}{ Sample type } & \multicolumn{2}{|c|}{ Mean \pm SD } & \multicolumn{2}{|c|}{ Min } & \multicolumn{2}{|c|}{$\operatorname{Max}$} & \multirow[t]{2}{*}{$\mathrm{D}$-excess mean $\pm \mathrm{SD}$} & \multirow[t]{2}{*}{$N$} \\
\hline & $\delta^{2} \mathrm{H}(\% o)$ & $\delta^{18} \mathrm{O}(\% o)$ & $\delta^{2} \mathrm{H}(\% o)$ & $\delta^{18} \mathrm{O}(\% o)$ & $\delta^{2} \mathrm{H}(\% \circ)$ & $\delta^{18} \mathrm{O}(\% o)$ & & \\
\hline Precipitation & $-43.9 \pm 23.4$ & $-6.2 \pm 3.1$ & -167.6 & -22.4 & -8.3 & -1.2 & $5.9 \pm 5.7$ & 592 \\
\hline Vollnkirchener Bach & $-58.0 \pm 2.8$ & $-8.4 \pm 0.4$ & -66.3 & -10.0 & -26.9 & -6.7 & $9.0 \pm 2.3$ & 332 \\
\hline Schwingbach & $-58.2 \pm 4.3$ & $-8.4 \pm 0.6$ & -139.7 & -18.3 & -47.2 & -5.9 & $9.0 \pm 2.2$ & 463 \\
\hline Groundwater meadow & $-57.6 \pm 1.6$ & $-8.2 \pm 0.4$ & -64.9 & -9.2 & -50.8 & -5.7 & $7.9 \pm 5.5$ & 375 \\
\hline Groundwater arable land & $-56.2 \pm 3.7$ & $-8.0 \pm 0.5$ & -91.6 & -12.3 & -49.5 & -6.8 & $1.7 \pm 5.0$ & 338 \\
\hline Groundwater along stream & $-59.9 \pm 6.8$ & $-8.5 \pm 0.9$ & -94.5 & -13.0 & -49.5 & -7.0 & $8.2 \pm 1.5$ & 108 \\
\hline
\end{tabular}

isotope data sets, despite some differences in the exact cluster centroid locations. We therefore decided to use randomly selected $80 \%$ of the isotope time series to illustrate our results. In the network map, each node of the network represents an isotope sampling point. The locations of the nodes are based on the first two components (PC1 and PC2). The correlations between isotope time series are represented by the edges connecting nodes. The thickness of edges characterizes the strength of the correlations. The $p$ values of correlations are approximated by using the $\mathrm{F}$ distributions and mid-ranks are used for the ties (Hollander et al., 2013). Only statistically significant connections $(p<0.05)$ are shown.

To compare different water sources on the catchment scale, a local meteoric water line (LMWL) was developed and evaporation water lines (EWLs) were used. They represent the linear relationship between $\delta^{2} \mathrm{H}$ and $\delta^{18} \mathrm{O}$ of meteoric waters (Cooper, 1998) in contrast to the global meteoric water line (GMWL), which describes the worldwide average stable isotopic composition in precipitation (Craig, 1961a). Identifying the origin of water vapour sources and moisture recycling (Gat et al., 2001; Lai and Ehleringer, 2011), the deuterium excess (d excess), defined by Dansgaard (1964) as $\mathrm{d}=\delta^{2} \mathrm{H}-8 \times \delta^{18} \mathrm{O}$ was used.

For comparisons, precipitation isotope data from the closest GNIP (Global Network of Isotopes in Precipitation) station Koblenz (DE; $74 \mathrm{~km} \mathrm{SW}$ of the study area, $97 \mathrm{~m}$ a.s.l.) were used (IAEA, 2014; Stumpp et al., 2014). For monthly comparisons with Schwingbach d-excess values, we used a data set from the GNIP station Koblenz that includes 24 values starting from July 2011 to July 2013.

\section{Results}

\subsection{Variations of precipitation isotopes and $d$ excess}

The $\delta^{2} \mathrm{H}$ values of all precipitation isotope samples ranged from -167.6 to $-8.3 \%$ (Table 1 ). To examine the spatial isotopic variations, rainfall was collected at 15 open-field site locations throughout the Schwingbach main catchment (Fig. 1b-c) for a 7-month period, but no spatial variation could be observed. Thus, rainfall was collected at the catchment outlet (site 13) from 23 October 2014 onward. We could neither identify an amount effect nor an altitude effect in our precipitation isotope data. The greatest altitudinal difference between sampling points was also only $101 \mathrm{~m}$. Nevertheless, a slight temperature effect $\left(R^{2}=0.5\right.$ for $\delta^{2} \mathrm{H}$ and $R^{2}=0.6$ for $\delta^{18} \mathrm{O}$ ) was observed showing enriched isotopic signatures at higher temperatures.

Strong temporal variations in precipitation isotopic signatures as well as pronounced seasonal isotopic effects were measured, with greatest isotopic differences occurring between summer and winter. Samples taken in the fall and spring were isotopically similar but differed from winter isotopic signature, which were somewhat lighter (Fig. 2). Furthermore, in the winter of 2012-2013 snow was sampled, which decreased the mean winter isotopic values for this period in comparison to the previous winter period (20112012) where no snow sampling could be conducted. The mean $\delta^{2} \mathrm{H}$ isotope values of snow samples were approximately $84 \%$ o lighter than mean precipitation isotopic signatures (Fig. 3). Furthermore, no statistically significant $(p>0.05)$ interannual variation was detected between the summer periods of 2011 and 2012 (Fig. 2).

Examining the influence of moisture recycling on the isotopic compositions of precipitation, the d excess was calculated for each individual rain event at the Schwingbach catchment. D excess values ranged from -7.8 to $+19.4 \%$ o and averaged $+7.1 \%$ (Fig. 2). In general, $37 \%$ of all events were sampled in summer periods (21 June-21/22 September). These summer events showed lower d-excess values in comparison to the $19 \%$ winter precipitation events $(21 / 22$ December to $19 / 20$ March) (Fig. 2). D excess greater than $+10 \%$ was determined for $22 \%$ of all events. Lowest values corresponded to summer precipitation events where evaporation of the raindrops below the cloud base may occur. Most of the higher values $(>+10 \%$ ) appeared in cold seasons (fall or winter) and winter snow samples of the Schwingbach catchment with much depleted $\delta$ values showed highest d excess (Fig. 2).

In comparison with the GNIP station Koblenz (20112013), the mean annual d excess at the Schwingbach catchment was on average $3.9 \%$ higher, showing a greater impact of oceanic moisture sources than the station Koblenz, located further south-west. The long-term mean d excess was $4.4 \%$ o 
for the Koblenz station (1978-2009) (Stumpp et al., 2014). Highest $\mathrm{d}$ excesses at the GNIP station matched the highest values in the Schwingbach catchment, both occurring in the cold seasons (October to December 2011 and November to December 2012).

The linear relationship of $\delta^{2} \mathrm{H}$ and $\delta^{18} \mathrm{O}$ content in local precipitation, results in a local meteoric water line (LMWL) (Fig. 3). The slope of the Schwingbach LMWL is in good agreement with the one from the GNIP station Koblenz $\left(\delta^{2} \mathrm{H}=7.66 \times \delta^{18} \mathrm{O}+2.0 \%\right.$; $R^{2}=0.97 ; \quad 1978$ 2009; Stumpp et al., 2014) but is slightly lower in comparison to the GMWL, showing stronger local evaporation conditions. Since evaporation causes a differential increase in $\delta^{2} \mathrm{H}$ and $\delta^{18} \mathrm{O}$ values of the remaining water, the slope for the linear relationship between $\delta^{2} \mathrm{H}$ and $\delta^{18} \mathrm{O}$ is lower in comparison to the GMWL (Rozanski et al., 2001; Wu et al., 2012).

\subsection{Isotopes of soil water}

\subsubsection{Spatial variability}

Determining the impact of landscape characteristics on soil water isotopic signatures, we found no statistically significant connection between the parameters' distance to stream, TWI, soil water content, soil texture, $\mathrm{pH}$, and bulk density with the soil isotopic signatures at both soil depths, except for land use.

The mean $\delta$ values in the top $0.2 \mathrm{~m}$ of the soil profile are higher than in the subsoil, reflecting a stronger impact of precipitation in the topsoil (Table 2, Fig. 4). While the $\delta$ values for subsoil and precipitation differed significantly $(p \leq 0.05)$, they did not do so for topsoil (Fig. 4). Subsoil isotopic values were statistically equal to stream water and groundwater (Fig. 4).

Generally, all soil water isotopic values fell on the LMWL, indicating no evaporative enrichment (Fig. 5). Comparing soil isotopic signatures between different land covers showed generally higher and statistically significantly different $\delta$ values $(p \leq 0.05)$ at $0.2 \mathrm{~m}$ soil depth under arable land as compared to forests and grasslands. For the lower $0.5 \mathrm{~m}$ of the soil column, isotopic signatures under all land uses showed statistically similar values. Comparing soil water $\delta^{2} \mathrm{H}$ values between top- and subsoil under different land use units showed significant differences $(p \leq 0.05)$ under arable and grassland but not under forested sites (Fig. 5).

\subsubsection{Seasonal isotope soil profiling}

Isotope compositions of soil water varied seasonally: more depleted soil water was found in the winter and spring (Fig. 6); by contrast, soil water was enriched in summer due to evaporation during warmer and drier periods (Darling, 2004). For summer soil profiles in the Vollnkirchener subcatchment, no evidence for evaporation was obvious below $0.4 \mathrm{~m}$ soil depth. However, snowmelt isotopic signatures could be traced down to a soil depth of $0.9 \mathrm{~m}$ during spring rather than winter, pointing to a depth translocation of meltwater in the soil, more remarkable for the deeper profile under arable land (Fig. 6, upper left panel). Furthermore, shallow soil water $(<0.4 \mathrm{~m})$ showed larger standard deviations with values closer to mean seasonal precipitation inputs (Fig. 6, upper panels). Winter profiles exhibited somewhat greater standard deviations in comparison to summer isotopic soil profiles. The observed seasonal amplitude became less pronounced with depth as soil water isotope signals approached a groundwater average at $>0.9 \mathrm{~m}$ depth. Generally, deeper soil water isotope values were relatively constant through time and space.

\subsection{Isotopes of stream water}

No statistically significant differences were found between the Schwingbach and Vollnkirchener Bach stream water (Fig. 7). All stream water isotope samples fell on the LMWL except for a few evaporatively enriched samples (Fig. 3). $\delta^{18} \mathrm{O}$ values varied for the Vollnkirchener Bach by $-8.4 \pm 0.4 \%$ and for the Schwingbach by $-8.4 \pm 0.6 \%$ o (Table 1). Stream water isotopic signatures were by approximately $-15 \%$ in $\delta^{2} \mathrm{H}$ more depleted than precipitation signatures and were similar to groundwater (Table 1).

A damped seasonality of the isotope concentration in stream water versus precipitation occurred between summer and winter (Fig. 7). Most outlying depleted stream water isotopic signatures (e.g. in March 2012 and 2013) can be explained by snowmelt (Fig. 7). However, the outlier at the Schwingbach stream water sampling site $64(-66.7 \%$ o for $\left.\delta^{2} \mathrm{H}\right)$ is $8.5 \%$ o more depleted than the 2-year average of Schwingbach stream water (Table 1). Rainfall falling on 24 September 2012 was $-31.9 \%$ for $\delta^{2} \mathrm{H}$. This period in September was generally characterized by low flow and little rainfall. Thus, little contribution of new water was observed and stream water isotopic signatures were groundwaterdominated. For site 13, the outlier in May $2012(-44.2 \%$ o for $\delta^{2} \mathrm{H}$ ) was $13.8 \%$ more enriched than the average stream water isotopic composition of the Vollnkirchener Bach over the 2-year observation period (Table 1). A runoff peak at site 13 of $0.15 \mathrm{~mm} \mathrm{day}^{-1}$ and a $2.9 \mathrm{~mm}$ rainfall event were recorded on 23 May 2012. Thus, this outlier could be explained by precipitation contributing to stream flow causing more enriched isotopic values in stream water, which approached average precipitation $\delta$ values $(-43.9 \pm 23.4)$.

MTT calculations for the Schwingbach and the Vollnkirchener Bach did not provide a good fit in terms of the quality criteria sigma and model efficiency (Timbe et al.,

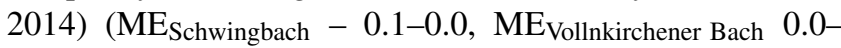
0.4 ; sigma for all sampling points 0.1 ). Bias correction of the input data did not improve the model outputs $(\operatorname{sigma}=0.1$ ). 
Table 2. Mean and standard deviation (SD) for isotopic signatures and soil physical properties at $0.2 \mathrm{~m}$ and $0.5 \mathrm{~m}$ soil depth $(N=52$ per depth).

\begin{tabular}{|c|c|c|c|c|c|c|c|c|c|c|}
\hline & \multicolumn{2}{|c|}{$\delta^{2} \mathrm{H}(\% \circ)$} & \multicolumn{2}{|c|}{$\delta^{18} \mathrm{O}(\% \circ)$} & \multicolumn{2}{|c|}{ Water content $(\% w / w)$} & \multicolumn{2}{|c|}{$\mathrm{pH}$} & \multicolumn{2}{|c|}{ Bulk density $\left(\mathrm{g} \mathrm{cm}^{-3}\right)$} \\
\hline & $0.2 \mathrm{~m}$ & $0.5 \mathrm{~m}$ & $0.2 \mathrm{~m}$ & $0.5 \mathrm{~m}$ & $0.2 \mathrm{~m}$ & $0.5 \mathrm{~m}$ & $0.2 \mathrm{~m}$ & $0.5 \mathrm{~m}$ & $0.2 \mathrm{~m}$ & $0.5 \mathrm{~m}$ \\
\hline Mean $\pm \mathrm{SD}$ & $-46.9 \pm 8.4$ & $-58.5 \pm 8.3$ & $-6.6 \pm 1.2$ & $-8.2 \pm 1.2$ & $16.8 \pm 7.2$ & $16.1 \pm 8.3$ & $5.0 \pm 1.0$ & $5.3 \pm 1.0$ & $1.3 \pm 0.2$ & $1.3 \pm 0.2$ \\
\hline
\end{tabular}

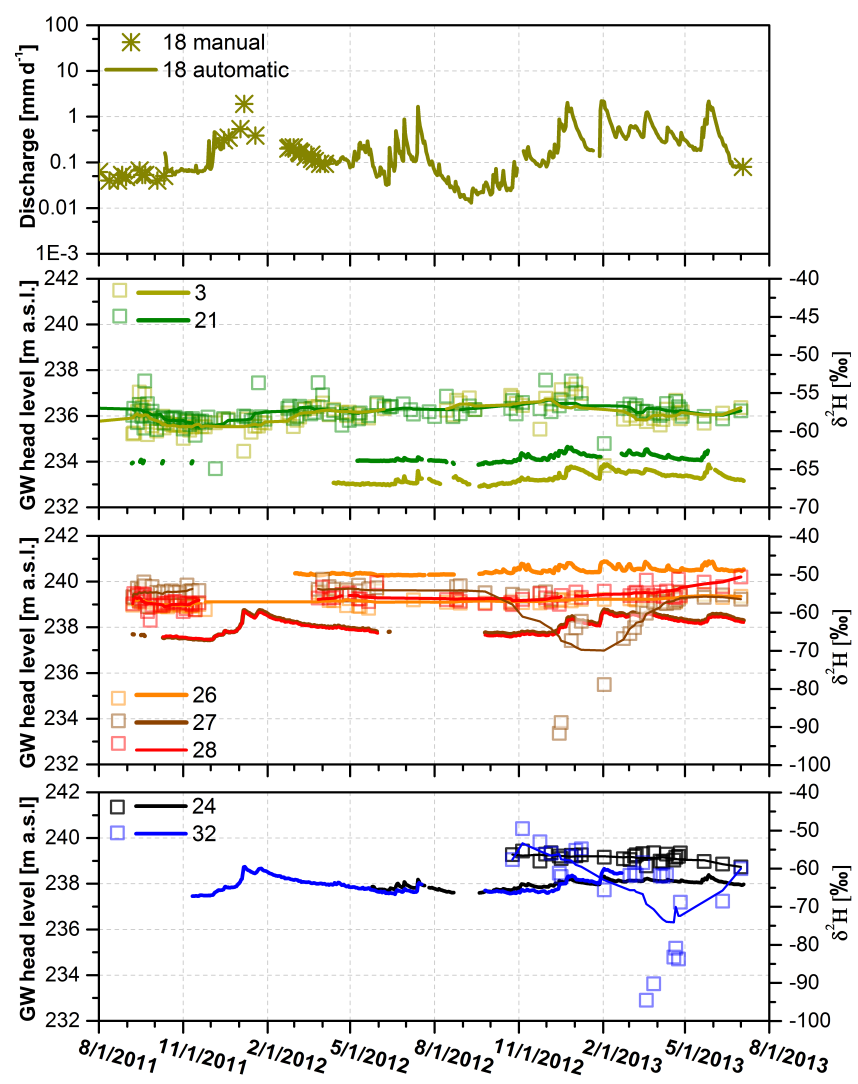

Figure 8. Temporal variation of discharge at the Vollnkirchener Bach with automatically recorded data (solid line) and manual discharge measurements (asterisks) (site 18), groundwater head levels, and $\delta^{2} \mathrm{H}$ values (coloured dots) for selected piezometers under the meadow (sites 3 and 21), arable land (sites 26, 27, and 28), and beside the Vollnkirchener Bach (sites 24 and 32) including moving averages for groundwater isotopes.

\subsection{Isotopes of groundwater}

For the piezometers under the meadow, almost constant isotopic values (Fig. 8, Table 1) were observed $\left(\delta^{2} \mathrm{H}\right.$ : $-57.6 \pm 1.6 \%$ o). Most depleted groundwater isotopic values $\left(<-80 \%\right.$ o for $\left.\delta^{2} \mathrm{H}\right)$ were measured for piezometer 32 during snowmelt events in March and April 2013 as well as for piezometer 27 from December 2012 to February 2013. Piezometer 32 is highly responsive to rainfall-runoff events and groundwater head elevations showed significant correla-

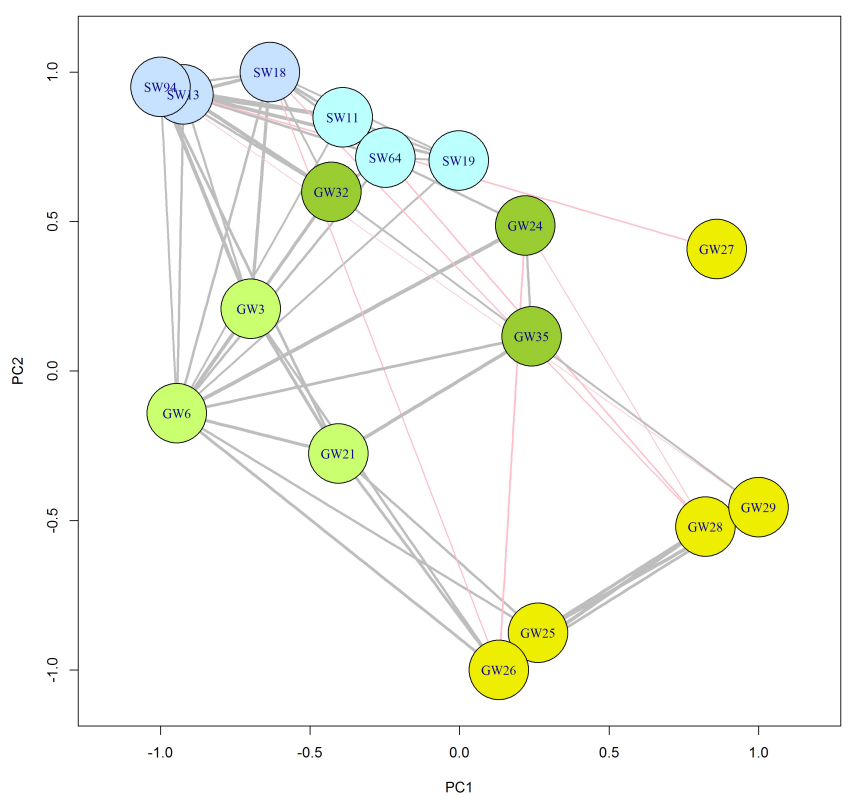

Figure 9. Network map of $\delta^{18} \mathrm{O}$ relationships between surface water $(\mathrm{SW})$ and groundwater $(\mathrm{GW})$ sampling points. Yellow circles represent groundwater sampling points on the arable field, light green circles are piezometers located on the grassland close to the conjunction of the Schwingbach with the Vollnkirchener Bach, and dark green circles represent piezometers along the Vollnkirchener Bach. Light blue circles stand for Schwingbach and darker blue circles for Vollnkirchener Bach surface water sampling points. See Fig. 1 for an overview of all sampling points. Only statistically significant connections between $\delta^{18} \mathrm{O}$ time series $(p<0.05)$ are shown in the network diagram.

tions with mean daily discharge at this site (Orlowski et al., 2014).

Groundwater under the meadow differed from mean precipitation values by about $-14 \%$ for $\delta^{2} \mathrm{H}$, showing no evidence of a rapid transfer of rainfall isotopic signatures to the groundwater (Fig. 8). For the MTT estimations of the 13 piezometers, the calculated output data did not fit the observed values, showing very low MEs (ME: $-0.62--0.09$ for $\delta^{18} \mathrm{O}$ and $-0.49-0.16$ for $\delta^{2} \mathrm{H}$; sigma: $0.08-0.15$ for $\delta^{18} \mathrm{O}$ and $0.62-1.11$ for $\delta^{2} \mathrm{H}$ ).

Due to different water flow paths of groundwater along the studied stream, we expected to find distinct groundwater isotopic signatures. In fact, we could identify spatial statistical differences between grassland and arable land groundwater isotopic signatures (Fig. 9). Groundwater isotopic signa- 


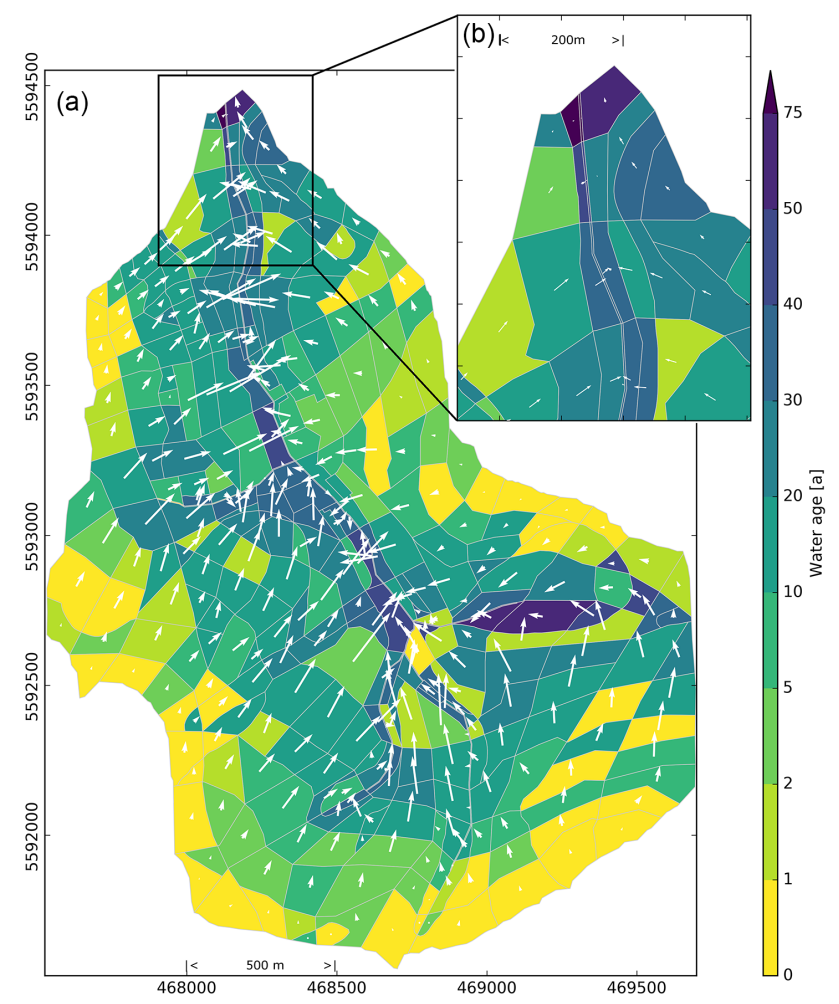

Figure 10. Maps of modelled groundwater ages (colour scheme) and flow directions (white arrows) of (a) the Vollnkirchener Bach subcatchment and (b) a detailed view of the northern part of the subcatchment. The length of the white arrows depicts the intensity of flow. UTM-32N (WGS84) coordinates on both axes.

tures under arable land (sites: 25-29, Fig. 1b) showed more enriched values (Fig. 8) and showed significant correlations $(p<0.05)$ among each other (Fig. 9). Arable land groundwater plotted furthest away from surface water sampling points in our network map, showing no significant correlations to either the Schwingbach or the Vollnkirchener Bach. $\delta^{18} \mathrm{O}$ time series of piezometers along the stream and under the meadow showed the closest relationship to surface water sampling points (Fig. 9). We further found high correlations $\left(R^{2}>0.6\right)$ of $\delta^{18} \mathrm{O}$ time series of piezometers located under the meadow with each other. Additionally, $\delta^{18} \mathrm{O}$ values of piezometer 3 correlated significantly $(p<0.05)$ with surface water sampling points 18 and $94\left(R^{2}=0.6\right.$ and 0.8 , respectively) and those of piezometer 32 with sampling points 13 and $64\left(R^{2}=0.8\right.$ and 0.6 , respectively).

We further observed a close relationship $(p<0.05)$ among $\delta^{18} \mathrm{O}$ values of Vollnkirchener Bach sampling sites 13, 18, and 94 as well as of Schwingbach sites 11, 19, and 64 along with significant correlations between each other.

\subsection{Groundwater age dynamics}

Since MTT calculations did not provide a good fit between the observed and calculated output data, we modelled the groundwater age in the Vollnkirchener Bach subcatchment using catchment modelling framework (CMF; Appendix B), applying observed hydrometric as well as stable water isotope data (Fig. 10).

The maximum age of water is highly variable throughout the subcatchment, which results in a heterogeneous spatial age distribution. The groundwater in most of the outer cells is young ( $0-10$ years), whereas the inner cells, which incorporate the Vollnkirchener Bach, contain older water ( $>30$ years). The oldest water ( $\geq 55$ years) can be found in the northern part of the catchment (Fig. 10, detail view), where the Vollnkirchener Bach drains into the Schwingbach. The main outlets of the subcatchment (dark red coloured cell and green cell) even reach an age of 100 and 55 years, respectively. This can be explained by the fact that it is the lowest cell within the subcatchment and that water accumulates here. The overall flow path to this cell is the longest and as a consequence the groundwater age in this cell is the highest.

In general, $2 \%$ of cells contain groundwater that is older than 50 years, $<1 \%$ reveal ages $>70$ years, $13 \%$ contain water with an age of less than 1 year, and $52 \%$ with an age $<15$ years. Thus, most of the cells contain young to moderately old water $(<15$ years), while few cells comprise old water ( $>50$ years). The average groundwater age in the Vollnkirchener Bach subcatchment is 16 years. Correlating the groundwater age with the distance to the stream, we found a linear correlation $\left(R^{2}=0.3\right)$ with a distinct trend. The water tends to be younger with greater distance to the stream.

The amount of flowing water depicted by the length of the arrows is generally higher near the stream, whereas in most of the outer cells the amount is very low (Fig. 10). The modelled main flow direction is towards the Vollnkirchener Bach, but many arrows show a flow direction across the stream, indicating bidirectional water exchange between the stream and the groundwater body.

\section{Discussion}

\subsection{Variations of precipitation isotopes and d excess}

We found no spatial variation in precipitation isotopes throughout the Schwingbach catchment. For north-western Europe, Mook et al. (1974) also observed that precipitation collected over periods of 8 and $24 \mathrm{~h}$ from three different locations within $6 \mathrm{~km}^{2}$ at the same elevation were consistent within $0.3 \%$ ofor $\delta^{18} \mathrm{O}$. Further, we detected no amount or altitude effect on isotopes in precipitation. Amount effects are generally most likely to occur in the tropics or for intense 
convective rain events and are not a key factor for explaining isotope distributions in German precipitation (Stumpp et al., 2014).

The observed linear relationship $\left(\delta^{18} \mathrm{O}=0.44 \mathrm{~T}-\right.$ $12.05 \%$ ) between air temperature and precipitation $\delta^{18} \mathrm{O}$ values compares reasonably well with a correlation reported by Yurtsever (1975) based on North Atlantic and European stations from the GNIP network $\delta^{18} \mathrm{O}=(0.521 \pm 0.014) T-(14.96 \pm 0.21) \%$. The same is true for a correlation found by Rozanski et al. (1982) for the GNIP station Stuttgart, $196 \mathrm{~km}$ south of the Schwingbach. Stumpp et al. (2014) analysed long-term precipitation data from meteorological stations across Germany and found that 23 out of 24 tested stations showed a positive long-term temperature trend over time. The observed correspondence between the degree of isotope depletion and the temperature reflects the influence of the temperature effect in the Schwingbach catchment, which mainly appears in continental, middle-high latitudes (Jouzel et al., 1997). Furthermore, the correlation between $\delta^{2} \mathrm{H}$ in monthly precipitations and local surface air temperature becomes increasingly stronger towards the centre of the continent (Rozanski et al., 1982). Thus, the observed seasonal differences in precipitation $\delta$ values in the Schwingbach catchment could mainly be attributed to seasonal differences in air temperature and the presence of snow in the winter of 2012-2013 (Fig. 2).

Precipitation events originating from oceanic moisture show d-excess values close to $+10 \%$ (Craig, 1961a; Dansgaard, 1964; Wu et al., 2012), and one of the main sources for precipitation in Germany is moisture from the Atlantic Ocean (Stumpp et al., 2014). Lowest values corresponded to summer precipitation events where the evaporation of the falling raindrops below the cloud base occurs. The same observations were made by Rozanski et al. (1982) for European GNIP stations. Winter snow samples of the Schwingbach catchment with very depleted $\delta$ values showed the highest dexcess values $(>+10 \%$ ), in good agreement with results of Rozanski et al. (1982) for European GNIP stations. The observed differences in d-excess values between the Schwingbach catchment and the GNIP station Koblenz can be attributed to differences in elevation range and the different regional climatic settings at both sites (Koblenz is located in the relatively warmer Rhine River valley).

\subsection{Isotopes of soil water}

\subsubsection{Spatial variability}

We found no statistically significant connection between the parameters' distance to stream, TWI, soil water content, soil texture, $\mathrm{pH}$, and bulk density with the soil isotopic signatures in both soil depths. This was potentially attributed to the small variation in soil textures (mainly clayey silts and loamy sandy silts), bulk densities, and $\mathrm{pH}$ values for both soil depths (Table 2). Garvelmann et al. (2012) obtained high-resolution $\delta^{2} \mathrm{H}$ vertical depth profiles of pore water at various points along two fall lines of a pasture hillslope in the Black Forest (Germany) by applying the $\mathrm{H}_{2} \mathrm{O}$ (liquid)- $\mathrm{H}_{2} \mathrm{O}$ (vapour) equilibration laser spectroscopy method. The authors showed that groundwater was flowing through the soil in the riparian zone (downslope profiles) and dominated streamflow during baseflow conditions. Their comparison indicated that the percentage of pore water soil samples with a very similar stream water $\delta^{2} \mathrm{H}$ signature increases towards the stream channel (Garvelmann et al., 2012). In contrast, we found no such relationship between the distance to stream or TWI and soil isotopic values in the Vollnkirchener Bach subcatchment over various elevations (235-294 ma.s.l.) and locations. We attributed this to the gentle hillslopes and the low subsurface flow contribution in large parts of the catchment.

In our study, the $\delta$ values of topsoil and precipitation did not differ statistically (Fig. 4), but for precipitation and subsoil they did. The latter indicates either the influence of evaporation in the topsoil or the mixing with groundwater in the subsoil. However, a mixing and homogenization of new and old soil water with depth could not be seen clearly at $0.5 \mathrm{~m}$ soil depth, which would have resulted in a lower standard deviation (Song et al., 2011), but standard deviations of isotopic signatures in top- and subsoil were similar (Table 2). Subsoil isotopic values were statistically equal to stream water and groundwater (Fig. 4), implying that capillary rise of groundwater occurred. Overall, the rainfall isotopic signal was not directly transferred through the soil to the groundwater; even so the groundwater head level rose promptly after rainfall events. This behaviour reflects the differences of celerity and velocity in the catchment's rainfall-runoff response (McDonnell and Beven, 2014).

Soil water $\delta^{2} \mathrm{H}$ between top- and subsoil showed significant differences $(p \leq 0.05)$ under arable land and grassland but not under forested sites (Fig. 5). This could be explained through the occurrence of vertical preferential flow paths and interconnected macropore flow (Buttle and McDonald, 2002) characteristic of forested soils. Alaoui et al. (2011) showed that macropore flow with high interaction with the surrounding soil matrix occurred in forest soils, while macropore flow with low to mixed interaction with the surrounding soil matrix dominates in grassland soils. Seasonal tilling prevents the establishment of preferential flow paths under agricultural sites and is regularly done in the Schwingbach catchment, whereas the structure of forest soils, may remain uninterrupted throughout the entire soil profile for years (in particular the macropores and biopores) (Alaoui et al., 2011). This is reflected in the bulk density of the soils in the Schwingbach catchment, which increases from forests $\left(1.10 \mathrm{~g} \mathrm{~cm}^{-3}\right)$ to grassland $\left(1.25 \mathrm{~g} \mathrm{~cm}^{-3}\right)$ to arable land $\left(1.41 \mathrm{~g} \mathrm{~cm}^{-3}\right)$ in the topsoil. We infer that reduced hydrological connection between top- and subsoil under arable and grassland led to different isotopic signatures (Fig. 5).

Although vegetation cover has often shown an impact on soil water isotopes (Gat, 1996), only few data are available 
for Central Europe (Darling, 2004). Burger and Seiler (1992) found that soil water isotopic enrichment under spruce forest in Upper Bavaria was double that beneath neighbouring arable land, but soil isotope values were not comparable to groundwater (Burger and Seiler, 1992). Gehrels et al. (1998) also detected (though only slightly) heavier isotopic signatures under forested sites in the Netherlands in comparison to non-forested sites (grassland and heathland). By contrast, in southern Germany, Brodersen et al. (2000) observed only a negligible effect of throughfall isotopic signatures (of spruce and beech) on soil water isotopes, since soil water in the upper layers followed the seasonal trend in the precipitation input and had a very constant signature at greater depth. In a study by Sprenger et al. (2016b) the differences between the investigated soil profiles across the Attert catchment (LU) were mostly driven by soil types, which was also seen in the pore water stable isotope dynamics reported for soils in the Scottish Highlands (Geris et al., 2015). However, for the Schwingbach catchment, we conclude that the observed land use effect in the upper soil column is mainly attributed to different preservation and transmission of the precipitation input signal. It is most likely not attributable to distinguished throughfall isotopic signatures, the impact of evaporation or interception losses, since topsoil water isotopic signals followed the precipitation input signal under all land use units.

\subsubsection{Seasonal isotope soil profiling}

Soil water was enriched in summer due to evaporation during warmer and drier periods. The depth to which soil water isotopes are significantly affected by evaporation is rarely more than 1-2 $\mathrm{m}$ below ground and often less under temperate climates (Darling, 2004). In contrast, winter profiles exhibited somewhat greater standard deviations in comparison to summer isotopic soil profiles, indicative of wetter soils (Fig. 6, lower panels) and shorter residence times (Thomas et al., 2013). Isotope profiles taken during or after snowmelt in a study by Sprenger et al. (2016b) did not show an isotopic depletion at a certain depth as observed for example by Stumpp and Hendry (2012) and Peralta-Tapia et al. (2015). Generally, deeper soil water isotope values in our study were relatively constant through time and space. Similar findings were made by Foerstel et al. (1991) on a sandy soil in western Germany, by McConville et al. (2001) under predominately agriculturally used gley and till soils in Northern Ireland, Thomas et al. (2013) in a forested catchment in central Pennsylvania, USA, and by Bertrand et al. (2014) on the Pfyn alluvial forest (CH). Furthermore, Tang and Feng (2001) showed, for a sandy loam in New Hampshire (USA), that the influence of summer precipitation decreased with increasing depth, and soils at $0.5 \mathrm{~m}$ only received water from large storms. Pore water $\delta^{2} \mathrm{H}$ profiles taken at the catchment of the groundwater aquifer Freiburger Bucht (DE) in a study by Sprenger et al. (2016a) showed how the isotopic signal of rain water over time is preserved in the unsaturated soil profile.
However, the input signal was dampened due to mixing processes. In our summer soil profiles under arable land, precipitation input signals decreased with depth (Fig. 6, upper left panel). Dampening of precipitation's isotopic fluctuations with increasing soil depth was in line with other studies (e.g. Muñoz-Villers and McDonnell, 2012; Timbe et al., 2014; Wang et al., 2010). Generally, the replacement of old soil water with new infiltrating water is dependent on the frequency and intensity of precipitation and the soil texture, structure, wetness, and water potential of the soil ( $\mathrm{Li}$ et al., 2007; Tang and Feng, 2001). As a result, the amount of percolating water decreases with depth and consequently, deeper soil layers have less chance to obtain new water (Tang and Feng, 2001). In the growing season, the percolation depth is additionally limited by plants' transpiration (Tang and Feng, 2001). For the Schwingbach catchment we conclude that the percolation of new soil water is low as no remarkable seasonality in soil isotopic signatures was obvious at $>0.9 \mathrm{~m}$ and constant values were observed through space and time. Although replications over several years are missing, this result indicates a transit time through the rooting zone $(1 \mathrm{~m})$ of approximately 1 year.

\subsection{Linkages between water cycle components}

Stream water isotopic time series of the Vollnkirchener Bach and Schwingbach showed little deflections through time. Due to the observed isotopic similarities of stream and groundwater, we conclude that groundwater predominantly feeds baseflow (discharge $<10 \mathrm{~L} \mathrm{~s}^{-1}$ ). Even during peak flow occurring in January 2012 and December to April or May 2013, rainfall input did not play a major role for stream water isotopic composition although fast rainfall-runoff behaviours were observed by Orlowski et al. (2014). The damped groundwater isotopic signatures seemed to be a mixture of former lighter precipitation events and snowmelt, since meltwater is known to be depleted in stable isotopes as compared to precipitation or groundwater (Rohde, 1998) (Fig. 3). However, differences in the snow sampling method (new snow, snow pit layers, meltwater) can affect the isotopic composition (Penna et al., 2014; Taylor et al., 2001). As groundwater at the observed piezometers in the Vollnkirchener subcatchment is shallow (Orlowski et al., 2014), the snowmelt signal is able to move rapidly through the soil. Pulses of snowmelt water causing a depletion in spring and early summer were also observed by other studies (Darling, 2004; Kortelainen and Karhu, 2004). We therefore conclude that groundwater is mainly recharged throughout the winter. During spring runoff when soils are saturated, temperatures are low, and vegetation is inactive, recharge rates are generally highest. In contrast, recharge is very low during summer when most precipitation is transpired back to the atmosphere (Clark and Fritz, 1997a). Similarly, O'Driscoll et al. (2005) showed that summer precipitation does not significantly contribute to recharge in the Spring Creek watershed (Pennsylvania, USA) since $\delta^{18} \mathrm{O}$ 
values in summer precipitation were enriched compared to mean annual groundwater composition.

Further, Orlowski et al. (2014) showed that influent and effluent conditions (bidirectional water exchange) occurred simultaneously in different stream sections of the Vollnkirchener Bach, affecting stream and groundwater isotopic compositions equally. Our network map supported this assumption (Fig. 9) as surface water sampling points plotted close to groundwater sampling points (especially to the sampling points under the meadow and along the stream). This was also underlined by our groundwater model showing flow directions across the Vollnkirchener Bach. Nevertheless, both stream and groundwater differed significantly from rainfall isotopic signatures (Table 1). Thus, our catchment showed double water paradox behaviour as per Kirchner (2003), with fast release of very old water but little variation in tracer concentration.

\subsection{Water age dynamics}

Our MTT calculations did not provide a good fit between the observed and calculated data. Just by comparing mean precipitation, stream, and groundwater isotopic signatures (Table 1), one could expect that simple mixing calculations would not work to derive MTTs, i.e. showing predominant groundwater contribution. The same observations were made by Jin et al. (2012), indicating good hydraulic connectivity between surface water and shallow groundwater. Just as in the results presented here, Klaus et al. (2015) had difficulties to apply traditional methods of isotope hydrology (MTT estimation, hydrograph separation) to their data set due to the lack of temporal isotopic variation in stream water of a forested low mountainous catchment in South Carolina (USA). Furthermore, stable water isotopes can only be utilised for estimations of younger water $(<5$ years) (Stewart et al., 2010) as they are blind to older contributions (Duvert et al., 2016). In our catchment, transit times are orders of magnitudes longer than the timescale of hydrologic response (prompt discharge of old water) (McDonnell et al., 2010) and the range used for stable water isotopes.

Accurately capturing the transit time of the old water fraction is essential (Duvert et al., 2016) and could previously only be determined via other tracers such as tritium (e.g. Michel, 1992). Current studies on mixing assumptions either consider spatial or time-varying MTTs. Heidbüchel et al. (2012) proposed the concept of the master transit time distribution that accounts for the temporal variability of MTT. The time-varying transit time concept of Botter et al. (2011) and van der Velde et al. (2012) was recently reformulated by Harman (2015) so that the storage selection function became a function of the watershed storage and actual time. Instead of quantifying time-variant travel times, our model facilitates the estimation of spatially distributed groundwater ages, which opens up new opportunities to compare groundwater ages from over a range of scales within catchments. Further- more, it gives a deeper understanding of the groundwatersurface water connection across the landscape than a classical MTT calculation could provide. Our work complements recent advances in spatially distributed modelling of age distributions through transient groundwater flows (e.g. Gomez and Wilson, 2013; Woolfenden and Ginn, 2009). The results of our model reveal a spatially highly heterogeneous age distribution of groundwater throughout the Vollnkirchener Bach subcatchment (ages of 2 days-100 years), with the oldest water near the stream. Thus, our model provides the opportunity to make use of stable water isotope information along with climate, land use, and soil type data, in combination with a digital elevation map to estimate residence times $>5$ years. If stable water isotope information is used alone, it is known to cause a truncation of stream residence time distributions (Stewart et al., 2010). Further, our groundwater model suggests that the main groundwater flow direction is towards and across the stream and the quantity of flowing water is highest near the stream (Fig. 10). This further supports the assumption that stream water is mainly fed by older groundwater. Moreover, the simulation underlines the conclusion that the groundwater body and stream water are isotopically disconnected from the precipitation cycle, since only $13 \%$ of cells contained water with an age $<1$ year.

However, our semi-conceptual model approach also has some limitations. During model set-up a series of assumptions and simplifications were made to develop a realistic hydrologic model without a severe loss in performance. Due to the assumption of a constant groundwater recharge over the course of a year, no seasonality was simulated. Moreover, no spatial differences in soil properties of the groundwater layer were considered. Further, several parameters such as the depth of the groundwater body are only rough estimations, while others like evapotranspiration are based on simulations. Moreover, the groundwater body is highly simplified since, e.g., properties of the simulated aquifer are assumed to be constant over the subcatchment. Nevertheless, as shown by the diverse ages of water in the stream cells and the assumption of spatially gaining conditions, the model confirms that the stream contains water with different transit times and supports the assumption that surface and groundwater are isotopically disconnected from precipitation. Therefore, the stream water does not have a discrete age, but a distribution of ages due to variable flow paths (Stewart et al., 2010). In future models a more diverse groundwater body based on small-scale measurements of aquifer parameters should be implemented. Especially data of saturated hydraulic conductivity with a high spatial resolution, as well as the implementation of a temporal dynamic groundwater recharge could lead to an enhanced model performance. 


\section{Conclusions}

Conducting a stable water isotope study in the Schwingbach catchment helped to identify relationships between precipitation, stream, soil, and groundwater in a developed (managed) catchment. The close isotopic link between groundwater and the streams revealed that groundwater controls streamflow. Moreover, it could be shown that groundwater was predominately recharged during winter but was decoupled from the annual precipitation cycle. Although streamflow and groundwater head levels promptly responded to precipitation inputs, there was no obvious change in their isotopic composition due to rain events.

Nevertheless, the lack of temporal variation in stable isotope time series of stream and groundwater limited the application of classical methods of isotope hydrology, i.e. transferfunction-based MTT estimations. By splitting the flow path into different compartments (upper and lower vadose zone, groundwater, stream), we were able to determine, where the water age passes the limit of using stable isotopes for age calculations. This limit is in the lower vadose zone, approximately $1-2 \mathrm{~m}$ below ground. To estimate the total transit time to the stream, we set up a hydrological model calculating spatially distributed groundwater ages and flow directions in the Vollnkirchener Bach subcatchment. Our model results supported the finding that the water in the catchment is $>5$ years old (on average 16 years) and that stream water is mainly fed by groundwater. Our modelling approach was valuable to overcome the limitations of MTT calculations with traditional methods and/or models. Further, our dual isotope study in combination with the hydrological model approach enabled the determination of connection and disconnection between different water cycle components. 


\section{Appendix A: Mean transit time estimation}

We applied a set of five different models to estimate the MTT using the FlowPC software (Maloszewski and Zuber, 2002): a dispersion model (with different dispersion parameters $D_{\mathrm{p}}=0.05,0.4$, and 0.8 ), an exponential model, an exponential-piston-flow model, a linear model, and a linearpiston-flow model. We evaluated these results using two goodness-of-fit criteria, i.e. sigma $(\sigma)$ and model efficiency (ME) following Maloszewski and Zuber (2002):

$\sigma=\frac{\sqrt{\sum\left(c_{\mathrm{mi}}-c_{\mathrm{oi}}\right)^{2}}}{m}$,

$\mathrm{ME}=1-\frac{\sum\left(c_{\mathrm{mi}}-c_{\mathrm{oi}}\right)^{2}}{\sum\left(c_{\mathrm{oi}}-\overline{c_{\mathrm{o}}}\right)^{2}}$,

where $c_{\mathrm{mi}}$ is the $\mathrm{i}$-th model result, $c_{\mathrm{oi}}$ is the $\mathrm{i}$-th observed result, and $\overline{c_{\mathrm{o}}}$ is the arithmetic mean of all observations.

A model efficiency $\mathrm{ME}=1$ indicates an ideal fit of the model to the concentrations observed, while $\mathrm{ME}=0$ indicates that the model fits the data no better than a horizontal line through the mean observed concentration (Maloszewski and Zuber, 2002). The same is true for sigma. For calculations with FlowPC, weekly averages of precipitation and stream water isotopic signatures are calculated. We firstly calculated the MTT from precipitation to the streams for three sampling points in the Vollnkirchener Bach (sites 13, 18, and 94) and three points in the Schwingbach (sites 11, 19 , and 64). For the second set of simulations, the mean residence time from precipitation to groundwater comprising 13 groundwater sampling points was determined. We also bias-corrected the precipitation input data with two different approaches. The mean precipitation value is subtracted from every single precipitation value and then divided by the standard deviation of precipitation isotopic signatures. Afterwards, this value is subtracted from the weekly precipitation values (bias1). For the second approach, the difference in the mean stream water isotopic value and the mean precipitation value is calculated and also subtracted from the weekly precipitation values (bias2).

\section{Appendix B: Model-based groundwater age dynamics}

\section{B1 Objective}

Stable water isotopes are only a tool to determine the residence time for a few years (McDonnell et al., 2010). In cases of longer residence times and a strong mixing effect, seasonal variation of isotopes vanishes and results in barely varying isotopic signals. To get a rough estimate of residence times greater than the limit of stable water isotopes ( $>5$ years), we split the water flow path in our catchment in two parts: the flow from precipitation to groundwater, which was calculated via FlowPC and the longer groundwater transport. The simplest method to estimate the residence time of groundwater transport is via the storage-to-input relation, with the storage as the aquifer size and the input as the groundwater recharge time. However, this method ignores the topographic setting and water input heterogeneity. In our study we used a simplified groundwater flow model with tracer transport to calculate the groundwater age dynamics. The numerical output of water ages cannot be validated with the given isotope data, since the model is used to fill a residence time gap, where it is not feasible to apply stable water isotopes. The model is falsified, however, if the residence time is short enough ( $<5$ years) to be calculable via FlowPC. Hence, the results of the groundwater age model should be handled with care and only seen as the order of magnitude of flow timescales.

\section{B2 Model setup}

We set up a tailored hydrological model for the Vollnkirchener Bach subcatchment using the CMF by Kraft et al. (2011). CMF is a modular framework for hydrological modelling based on the concept of finite volume method by Qu and Duffy (2007). CMF is applicable for simulating oneto three-dimensional water fluxes but also advective transport of stable water isotopes $\left({ }^{18} \mathrm{O}\right.$ and $\left.{ }^{2} \mathrm{H}\right)$. Thus, it is especially suitable for our tracer study and can be used to study the origin (Windhorst et al., 2014) and age of water. To avoid errors in transit time calculations from small differences between the isotopic signal in groundwater and stream water, we are tracing the transit time of groundwater and not the real isotopic values in this study. The generated model is a highly simplified representation of the Vollnkirchener Bach subcatchment's groundwater body. The subcatchment is divided into 353 polygonal-shaped cells ranging from 100 to $40000 \mathrm{~m}^{2}$ in size based on land use, soil type, and topography. The model is vertically divided into two compartments, the upper soft rock aquifer, and the lower bedrock aquifer, referred to as upper and lower layer from now onwards.

The layers of each cell are connected using a mass conservative Darcy approach with a finite volume discretization. The water storage dynamic of one layer in one cell $i$ of the groundwater model is given as

$$
\begin{aligned}
& \frac{\mathrm{d} V_{i, \mathrm{~s}}}{\mathrm{~d} t}=R_{i}-S_{i}-\sum_{j=1}^{N_{i}}\left(K_{\mathrm{s}} \frac{\Psi_{i, \mathrm{~s}}-\Psi_{j, s}}{d_{i j}} A_{i j, \mathrm{~s}}\right), \\
& \frac{\mathrm{d} V_{i, b}}{\mathrm{~d} t}=S_{i}-\sum_{j=1}^{N_{i}}\left(K_{\mathrm{b}} \frac{\Psi_{i, \mathrm{~b}}-\Psi_{j, \mathrm{~b}}}{d_{i j}} A_{i j, \mathrm{~b}}\right),
\end{aligned}
$$

where $V_{i}$ is the water volume stored by the layer in $\mathrm{m}^{-3}$ in cell $I$ for soft rock (s) and bedrock (b); $R_{i}$ is the groundwater recharge rate in $\mathrm{m}^{2} \mathrm{day}^{-1} ; S_{i}$ is the percolation from the soft rock to the bedrock aquifer, calculated by the gradient and geometric mean conductivity between the layers: $S_{i}=\sqrt{K_{\mathrm{s}} K_{\mathrm{b}}} \frac{\Psi_{i, \mathrm{~s}}-\Psi_{i, \mathrm{~b}}}{d_{\mathrm{sb}}} A_{i}$, where $d_{\mathrm{sb}}$ is the distance between the layers and $A_{i}$ is the cell area; $N_{i}$ is the number of adjacent cells to cell $i ; K$ is the saturated hydraulic conductivity 
in $\mathrm{m} \mathrm{day}^{-1}$ for soft rock (s) and bedrock (b), respectively; $\Psi$ is the water head in the current cell $i$ and the neighbour cell $j$ in metres for soft rock (s) and bedrock (b); $d_{i j}$ is the distance between the current cell $i$ and the neighbour cell $j$ in metres; and $A_{i, j, x}$ is the wetted area of the joint layer boundary in $\mathrm{m}^{2}$ between cells $i$ and $j$ in layer $x$.

The volume head relation is linearized as $\Psi=\phi \frac{V}{A}$, with $\phi$ being the fillable porosity and $A$ the cell area. The resulting ordinary differential equation system is integrated using the CVODE solver by Hindmarsh et al. (2005), an errorcontrolled Krylov-Newton multistep implicit solver with an adaptive order of $1-5$ according to stability constraints.

\section{B3 Boundary conditions}

The upper boundary condition of the groundwater system - the mean groundwater recharge - is modelled applying a Richard's equation based model using measured rainfall data (2011-2013) and calculated evapotranspiration with the Shuttleworth-Wallace method (Shuttleworth and Wallace, 1985) including land cover and climate data. To retrieve long-term steady-state conditions, the groundwater recharge is averaged and used as a constant-flow Neumann boundary condition. The total outflow is calibrated against measured outflow data; hence, the unsaturated model's role is mainly to account for spatial heterogeneity of groundwater recharge. As an additional input, a combined sewer overflow (site 38, Fig. 1b) is considered based on findings of Orlowski et al. (2014). Moreover, there are two water outlets in the two lowest cells for efficient draining, reflecting measured groundwater flow directions throughout most of the year at piezometers 1-6 (Fig. 1b). Both cells are located in the very north of the subcatchment and their outlets are modelled as constant head Dirichlet boundary condition.

\section{B4 Parameters}

The saturated hydraulic conductivity of the groundwater body is set to $0.1007 \mathrm{~m} \mathrm{day}^{-1}$, as measured in the study area. For the lower bedrock compartment there are no data available. However, expecting a high rate of joints, preliminary testing revealed that a saturated hydraulic conductivity of $0.25 \mathrm{~m} \mathrm{day}^{-1}$ seemed to be a realistic estimation (based on field measurements).

\section{B5 Water age}

To calculate the water age in each cell, a virtual tracer flows through the system using advective transport. To calculate the water age from the tracer that enters the system with a unity concentration by groundwater recharge, a linear decay is used to reduce the tracer concentration with time:

$$
\begin{aligned}
\frac{\mathrm{d} X_{i, s}}{\mathrm{~d} t}= & 1 \frac{u}{m^{3}} R_{i}-S_{i}[X]_{i, s} \\
& -\sum_{j=1}^{N_{i}}\left([X]_{i, s} K_{s} \frac{\Psi_{i, s}-\Psi_{j, s}}{d_{i j}} A_{i j, s}\right)-r X_{i, s}, \\
\frac{\mathrm{d} X_{i, b}}{\mathrm{~d} t} & =S_{i}[X]_{i, s}-\sum_{j=1}^{N_{i}}\left([X]_{i, b} K_{\mathrm{b}} \frac{\Psi_{i, b}-\Psi_{j, b}}{\mathrm{~d}_{i j}} A_{i j, b}\right) \\
& -r X_{i, b} t_{i x}=\frac{\ln [X]_{i x}}{r},
\end{aligned}
$$

where $X_{i, x}$ is the amount of virtual tracer in layer $x$ in cell $i$ in virtual unit $u ; 1 u \mathrm{~m}^{-3} R_{i}$ is the tracer input with groundwater recharge $R$ with unity concentration; $[X]_{i, x}$ is the concentration of tracer in layer $x$ of cell $i$ in $u \mathrm{~m}^{-3} ; r$ is the arbitrarily chosen decay constant, for water age calculation in day ${ }^{-1}$ rounding errors occur due to low concentrations when $r$ is set to a high value and we found a good numerical performance with values between $10^{-6}$ and $10^{-9} \mathrm{day}^{-1}$; and $t_{i x}$ : water age in days in layer $x$ in cell $i$.

To ensure long-term steady-state conditions, the model is run for 2000 years. However, after 300 years of model run time, steady state is reached. 
Acknowledgements. The first author acknowledges financial support by the Friedrich-Ebert-Stiftung (Bonn, DE). Furthermore, this work was supported by the Deutsche Forschungsgemeinschaft under Grant BR2238/10-1. Thanks also to the student assistants and BSc and MSc students for their help during field sampling campaigns and hydrological modelling. In this context we would like to acknowledge especially Julia Mechsner, Julia Klöber, and Judith Henkel. We thank Christine Stumpp from the Helmholtz Zentrum München for providing us with the isotope data from GNIP station Koblenz. We thank Kwok Pan (Sun) Chun for statistical support and suggestions along the way.

Edited by: M. Weiler

Reviewed by: four anonymous referees

\section{References}

Alaoui, A., Caduff, U., Gerke, H. H., and Weingartner, R.: Preferential Flow Effects on Infiltration and Runoff in Grassland and Forest Soils, Vadose Zone J., 10, 367-377, doi:10.2136/vzj2010.0076, 2011.

Allan, J. D.: Landscapes and Riverscapes: The Influence of Land Use on Stream Ecosystems, Annu. Rev. Ecol. Evol. Syst., 35, 257-284, doi:10.1146/annurev.ecolsys.35.120202.110122, 2004.

Barnes, C. J. and Allison, G. B.: Tracing of water movement in the unsaturated zone using stable isotopes of hydrogen and oxygen, J. Hydrol., 100, 143-176, doi:10.1016/0022-1694(88)90184-9, 1988.

Barthold, F. K., Tyralla, C., Schneider, K., Vaché, K. B., Frede, H.G., and Breuer, L.: How many tracers do we need for end member mixing analysis (EMMA)? A sensitivity analysis, Water Resour. Res., 47, W08519, doi:10.1029/2011WR010604, 2011.

Bertrand, G., Masini, J., Goldscheider, N., Meeks, J., Lavastre, V., Celle-Jeanton, H., Gobat, J.-M., and Hunkeler, D.: Determination of spatiotemporal variability of tree water uptake using stable isotopes $\left(\delta^{18} \mathrm{O}, \delta^{2} \mathrm{H}\right)$ in an alluvial system supplied by a highaltitude watershed, Pfyn forest, Switzerland, Ecohydrol., 7, 319 333, doi:10.1002/eco.1347, 2014.

Blasch, K. W. and Bryson, J. R.: Distinguishing Sources of Ground Water Recharge by Using $\delta^{2} \mathrm{H}$ and $\delta^{18} \mathrm{O}$, Ground Water, 45, 294308, doi:10.1111/j.1745-6584.2006.00289.x, 2007.

Botter, G., Bertuzzo, E., and Rinaldo, A.: Transport in the hydrologic response: Travel time distributions, soil moisture dynamics, and the old water paradox, Water Resour. Res., 46, W03514, doi:10.1029/2009WR008371, 2010.

Botter, G., Bertuzzo, E., and Rinaldo, A.: Catchment residence and travel time distributions: The master equation, Geophys. Res. Lett., 38, L11403, doi:10.1029/2011GL047666, 2011.

Brodersen, C., Pohl, S., Lindenlaub, M., Leibundgut, C., and Wilpert, K. V: Influence of vegetation structure on isotope content of throughfall and soil water, Hydrol. Process., 14, 14391448, doi:10.1002/1099-1085(20000615)14:8<1439::AIDHYP985>3.0.CO;2-3, 2000.

Burger, H. M. and Seiler, K. P.: Evaporation from soil water under humid climate conditions and its impact on deuterium and ${ }^{18} \mathrm{O}$ concentrations in groundwater, edited by: International Atomic
Energy Agency, International Atomic Energy Agency, Vienna, Austria, 674-678, 1992.

Buttle, J. M.: Isotope hydrograph separations and rapid delivery of pre-event water from drainage basins, Prog. Phys. Geogr., 18, 16-41, doi:10.1177/030913339401800102, 1994.

Buttle, J. M.: Isotope Hydrograph Separation of Runoff Sources, in Encyclopedia of Hydrological Sciences, edited by: Anderson, M. G., p. 10, 116, John Wiley \& Sons, Ltd, Chichester, Great Britain, 2006.

Buttle, J. M. and McDonald, D. J.: Coupled vertical and lateral preferential flow on a forested slope, Water Resour. Res., 38, 18-118-16, doi:10.1029/2001WR000773, 2002.

Clark, I. D. and Fritz, P.: Groundwater, in Environmental Isotopes in Hydrogeology, p. 80, CRC Press, Florida, FL, USA, 1997a.

Clark, I. D. and Fritz, P.: Methods for Field Sampling, in Environmental Isotopes in Hydrogeology, p. 283, CRC Press, Florida FL, USA, 1997b.

Clark, I. D. and Fritz, P.: The Environmental Isotopes, in: Environmental Isotopes in Hydrogeology, 2-34, CRC Press, Florida, FL, USA, 1997c.

Cooper, L. W.: Isotopic Fractionation in Snow Cover, in Isotope Tracers in Catchment Hydrology, edited by: Kendall, C. and McDonnell, J. J., 119-136, Elsevier, Amsterdam, the Netherlands, 1998.

Craig, H.: Isotopic Variations in Meteoric Waters, Science, 133, 1702-1703, doi:10.1126/science.133.3465.1702, 1961a.

Craig, H.: Standard for reporting concentrations of deuterium and oxygen-18 in natural waters, Science, 133, 1833-1834, doi:10.1126/science.133.3467.1833, 1961b.

Csardi, G. and Nepusz, T.: The igraph software package for complex network research, Complex Systems 1695, available at: http://igraph.sf.net (last access: 24 December 2015), 2006.

Dansgaard, W.: Stable isotopes in precipitation, Tellus, 16, 436468, doi:10.1111/j.2153-3490.1964.tb00181.x, 1964.

Darling, W. G.: Hydrological factors in the interpretation of stable isotopic proxy data present and past: a European perspective, Quat. Sci. Rev., 23, 743-770, doi:10.1016/j.quascirev.2003.06.016, 2004.

Duvert, C., Stewart, M. K., Cendón, D. I., and Raiber, M.: Time series of tritium, stable isotopes and chloride reveal short-term variations in groundwater contribution to a stream, Hydrol. Earth Syst. Sci., 20, 257-277, doi:10.5194/hess-20-257-2016, 2016.

DWD: Deutscher Wetterdienst - Wetter und Klima, Bundesministerium für Verkehr und digitale Infrastruktur, available at: http: //dwd.de/ (last access: 17 February 2014), 2014.

Foerstel, H., Frinken, J., Huetzen, H., Lembrich, D., and Puetz, T.: Application of $\mathrm{H}_{2}^{18} \mathrm{O}$ as a tracer of water flow in soil, International Atomic Energy Agency, Vienna, Austria, 523-532, 1991.

Garvelmann, J., Kuells, C., and Weiler, M.: A porewater-based stable isotope approach for the investigation of subsurface hydrological processes, Hydrol. Earth Syst. Sci., 16, 631-640, doi:10.5194/hess-16-631-2012, 2012.

Gat, J. R.: Oxygen and Hydrogen Isotopes in the Hydrologic Cycle, Annu. Rev. Earth Planet. Sci., 24, 225-262, doi:10.1146/annurev.earth.24.1.225, 1996.

Gat, J., R., Mook, W. G., and Meijer, H. A. J.: Environmental isotopes in the hydrological cycle: Principles and Applications, edited by: Mook, W. G., International Hydrological Programme, United Nations Educational, Scientific and Cultural Organization 
and International Atomic Energy Agency, Paris, France, p. 73, 2001.

Gehrels, J. C., Peeters, J. E. M., de Vries, J. J., and Dekkers, M.: The mechanism of soil water movement as inferred from ${ }^{18} \mathrm{O}$ stable isotope studies, Hydrol. Sci. J., 43, 579-594, doi:10.1080/02626669809492154, 1998.

Genereux, D. P. and Hooper, R. P.: Oxygen and Hydrogen Isotopes in Rainfall-Runoff Studies, in Isotope Tracers in Catchment Hydrology, edited by: Kendall, C. and McDonnell, J. J., 319-346, Elsevier, Amsterdam, the Netherlands, 1998.

Geris, J., Tetzlaff, D., McDonnell, J., and Soulsby, C.: The relative role of soil type and tree cover on water storage and transmission in northern headwater catchments, Hydrol. Process., 29, 18441860, doi:10.1002/hyp.10289, 2015.

Gomez, J. D. and Wilson, J. L.: Age distributions and dynamically changing hydrologic systems: Exploring topography-driven flow, Water Resour. Res., 49, 1503-1522, doi:10.1002/wrcr.20127, 2013.

Gonfiantini, R., Fröhlich, K., Araguás-Araguás, L., and Rozanski, K.: Isotopes in Groundwater Hydrology, in Isotope Tracers in Catchment Hydrology, edited by: Kendall, C. and McDonnell, J. J., 203-246, Elsevier, Amsterdam, the Netherlands, 1998.

Gordon, L. J., Finlayson, C. M., and Falkenmark, M.: Managing water in agriculture for food production and other ecosystem services, Agr. Water Manag., 97, 512-519, doi:10.1016/j.agwat.2009.03.017, 2010.

Harman, C. J.: Time-variable transit time distributions and transport: Theory and application to storage-dependent transport of chloride in a watershed, Water Resour. Res., 51, 1-30, doi:10.1002/2014WR015707, 2015.

Heidbüchel, I., Troch, P. A., Lyon, S. W., and Weiler, M.: The master transit time distribution of variable flow systems, Water Resour. Res., 48, W06520, doi:10.1029/2011WR011293, 2012.

Hindmarsh, A. C., Brown, P. N., Grant, K. E., Lee, S. L., Serban, R., Shumaker, D. E., and Woodward, C. S.: SUNDIALS: Suite of Nonlinear and Differential/Algebraic Equation Solvers, ACM Trans. Math. Softw., 31, 363-396, doi:10.1145/1089014.1089020, 2005.

Hollander, M., Wolfe, D. A., and Chicken, E.: Nonparametric Statistical Methods, John Wiley \& Sons, New York, NY, USA., 2013.

Hrachowitz, M., Benettin, P., van Breukelen, B. M., Fovet, O., Howden, N. J. K., Ruiz, L., van der Velde, Y., and Wade, A. J.: Transit times - the link between hydrology and water quality at the catchment scale, Wiley Interdiscip. Rev. Water, 3, 629-657, doi:10.1002/wat2.1155, 2016.

IAEA: International Atomic Energy Agency: Water Resources Programme - Global Network of Isotopes in Precipitation, available at: http://www-naweb.iaea.org/napc/ih/IHS_resources_ gnip.html (last access: 11 August 2014), 2014.

Jin, L., Siegel, D. I., Lautz, L. K., and Lu, Z.: Identifying streamflow sources during spring snowmelt using water chemistry and isotopic composition in semi-arid mountain streams, J. Hydrol., 470-471, 289-301, doi:10.1016/j.jhydrol.2012.09.009, 2012.

Jouzel, J., Alley, R. B., Cuffey, K. M., Dansgaard, W., Grootes, P., Hoffmann, G., Johnsen, S. J., Koster, R. D., Peel, D., Shuman, C. A., Stievenard, M., Stuiver, M., and White, J.: Validity of the temperature reconstruction from water isotopes in ice cores, J. Geophys. Res., 102, 26471-26487, doi:10.1029/97JC01283, 1997.
Kendall, C. and Caldwell, E. A.: Fundamentals of Isotope Geochemistry, in Isotope Tracers in Catchment Hydrology, edited by: Kendall, C. and McDonnell, J. J., 51-86, Elsevier, Amsterdam, the Netherlands, 1998.

Kirchner, J. W.: A double paradox in catchment hydrology and geochemistry, Hydrol. Process., 17, 871-874, doi:10.1002/hyp.5108, 2003.

Klaus, J., McDonnell, J. J., Jackson, C. R., Du, E., and Griffiths, N. A.: Where does streamwater come from in low-relief forested watersheds? A dual-isotope approach, Hydrol. Earth Syst. Sci., 19, 125-135, doi:10.5194/hess-19-125-2015, 2015.

Koeniger, P., Leibundgut, C., and Stichler, W.: Spatial and temporal characterisation of stable isotopes in river water as indicators of groundwater contribution and confirmation of modelling results; a study of the Weser river, Germany, Isotopes Environ. Health Stud., 45, 289-302, doi:10.1080/10256010903356953, 2009.

Kolaczyk, E. D.: Statistical Analysis of Network Data with R, Springer Science \& Business Media, New York, NY, USA, 187$188,2014$.

Kortelainen, N. M. and Karhu, J. A.: Regional and seasonal trends in the oxygen and hydrogen isotope ratios of Finnish groundwaters: a key for mean annual precipitation, J. Hydrol., 285, 143-157, doi:10.1016/j.jhydrol.2003.08.014, 2004.

Kraft, P., Vaché, K. B., Frede, H.-G., and Breuer, L.: CMF: A Hydrological Programming Language Extension For Integrated Catchment Models, Environ. Model. Softw., 26, 828-830, doi:10.1016/j.envsoft.2010.12.009, 2011.

Lai, C.-T. and Ehleringer, J. R.: Deuterium excess reveals diurnal sources of water vapor in forest air, Oecologia, 165, 213-223, doi:10.1007/s00442-010-1721-2, 2011.

Lauer, F., Frede, H.-G., and Breuer, L.: Uncertainty assessment of quantifying spatially concentrated groundwater discharge to small streams by distributed temperature sensing, Water Resour. Res., 49, 400-407, doi:10.1029/2012WR012537, 2013.

LGR: Los Gatos Research, Greenhouse Gas, isotope and trace gas analyzers, available at: http://www.lgrinc.com/ (last access: 5 February 2013), 2013.

Li, F., Song, X., Tang, C., Liu, C., Yu, J., and Zhang, W.: Tracing infiltration and recharge using stable isotope in Taihang Mt., North China, Environ. Geol., 53, 687-696, doi:10.1007/s00254007-0683-0, 2007.

Maloszewski, P. and Zuber, A.: Manual on lumped parameter models used for the interpretation of environmental tracer data in groundwaters, in: Use of isotopes for analyses of flow and transport dynamics in groundwater systems, p. 50, International Atomic Energy Agency, Vienna, Austria, 2002.

McConville, C., Kalin, R. M., Johnston, H., and McNeill, G. W.: Evaluation of Recharge in a Small Temperate Catchment Using Natural and Applied $\delta^{18} \mathrm{O}$ Profiles in the Unsaturated Zone, Ground Water, 39, 616-623, doi:10.1111/j.17456584.2001.tb02349.x, 2001.

McDonnell, J. J. and Beven, K.: Debates - The future of hydrological sciences: A (common) path forward? A call to action aimed at understanding velocities, celerities and residence time distributions of the headwater hydrograph, Water Resour. Res., 50, 5342-5350, doi:10.1002/2013WR015141, 2014.

McDonnell, J. J., Sivapalan, M., Vaché, K., Dunn, S., Grant, G., Haggerty, R., Hinz, C., Hooper, R., Kirchner, J., Roderick, M. L., McDonnell, J. J., Sivapalan, M., Vaché, K., Dunn, S., Grant, 
G., Haggerty, R., Hinz, C., Hooper, R., Kirchner, J., Roderick, M. L., Selker, J., and Weiler, M.: Moving beyond heterogeneity and process complexity: a new vision for watershed hydrology, Water Resour. Res., 43, W07301, doi:10.1029/2006WR005467, 2007.

McDonnell, J. J., McGuire, K., Aggarwal, P., Beven, K. J., Biondi, D., Destouni, G., Dunn, S., James, A., Kirchner, J., Kraft, P., Lyon, S., Maloszewski, P., Newman, B., Pfister, L., Rinaldo, A., Rodhe, A., Sayama, T., Seibert, J., Solomon, K., Soulsby, C., Stewart, M., Tetzlaff, D., Tobin, C., Troch, P., Weiler, M., Western, A., Worman, A., and Wrede, S.: How old is streamwater? Open questions in catchment transit time conceptualization, modelling and analysis, Hydrol. Process., 24, 1745-1754, 2010.

McGuire, K. J. and McDonnell, J. J.: A review and evaluation of catchment transit time modeling, J. Hydrol., 330, 543-563, 2006.

Michel, R. L.: Residence times in river basins as determined by analysis of long-term tritium records, J. Hydrol., 130, 367-378, doi:10.1016/0022-1694(92)90117-E, 1992.

Mook, W. G., Groeneveld, D. J., Brouwn, A. E., and van Ganswijk, A. J.: Analysis of a run-off hydrograph by means of natural ${ }^{18} \mathrm{O}$, in Isotope techniques in groundwater hydrology, 1, 159-169, International Atomic Energy Agency, Vienna, Austria, 1974.

Muñoz-Villers, L. E. and McDonnell, J. J.: Runoff generation in a steep, tropical montane cloud forest catchment on permeable volcanic substrate, Water Resour. Res., 48, W09528, doi:10.1029/2011WR011316, 2012.

Neal, C. and Rosier, P. T. W.: Chemical studies of chloride and stable oxygen isotopes in two conifer afforested and moorland sites in the British uplands, J. Hydrol., 115, 269-283, doi:10.1016/0022-1694(90)90209-G, 1990.

Newman, B., Tanweer, A., and Kurttas, T.: IAEA Standard Operating Procedure for the Liquid-Water Stable Isotope Analyser, Laser Proced, IAEA Water Resour. Programme, 2009.

O'Driscoll, M. A., DeWalle, D. R., McGuire, K. J., and Gburek, W. J.: Seasonal ${ }^{18} \mathrm{O}$ variations and groundwater recharge for three landscape types in central Pennsylvania, USA, J. Hydrol., 303, 108-124, doi:10.1016/j.jhydrol.2004.08.020, 2005.

Orlowski, N., Frede, H.-G., Brüggemann, N., and Breuer, L.: Validation and application of a cryogenic vacuum extraction system for soil and plant water extraction for isotope analysis, J. Sens. Sens. Syst., 2, 179-193, doi:10.5194/jsss-2-179-2013, 2013.

Orlowski, N., Lauer, F., Kraft, P., Frede, H.-G., and Breuer, L.: Linking Spatial Patterns of Groundwater Table Dynamics and Streamflow Generation Processes in a Small Developed Catchment, Water, 6, 3085-3117, doi:10.3390/w6103085, 2014.

Penna, D., Ahmad, M., Birks, S. J., Bouchaou, L., Brenčič, M., Butt, S., Holko, L., Jeelani, G., Martínez, D. E., Melikadze, G., Shanley, J. B., Sokratov, S. A., Stadnyk, T., Sugimoto, A., and Vreča, P.: A new method of snowmelt sampling for water stable isotopes, Hydrol. Process., 28, 5637-5644, doi:10.1002/hyp.10273, 2014.

Peralta-Tapia, A., Sponseller, R. A., Tetzlaff, D., Soulsby, C., and Laudon, H.: Connecting precipitation inputs and soil flow pathways to stream water in contrasting boreal catchments, Hydrol. Process., 29, 3546-3555, doi:10.1002/hyp.10300, 2015.

Perry, C. and Taylor, K.: Environmental Sedimentology, p. 36, Blackwell Publishing, Oxford, OX, UK, 2009.

Pierce, S. C., Kröger, R., and Pezeshki, R.: Managing Artificially Drained Low-Gradient Agricultural Headwaters for Enhanced Ecosystem Functions, Biology, 1, 794-856, doi:10.3390/biology1030794, 2012.

Qu, Y. and Duffy, C. J.: A semidiscrete finite volume formulation for multiprocess watershed simulation, Water Resour. Res., 43, W08419, doi:10.1029/2006WR005752, 2007.

Rinaldo, A., Benettin, P., Harman, C. J., Hrachowitz, M., McGuire, K. J., van der Velde, Y., Bertuzzo, E., and Botter, G.: Storage selection functions: A coherent framework for quantifying how catchments store and release water and solutes, Water Resour. Res., 51, 4840-4847, doi:10.1002/2015WR017273, 2015.

Rohde, A.: Snowmelt-Dominated Systems, in Isotope Tracers in Catchment Hydrology, edited by: Kendall, C. and McDonnell, J. J., 391-433, Elsevier, Amsterdam, the Netherlands, 1998.

Rozanski, K., Sonntag, C., and Münnich, K. O.: Factors controlling stable isotope composition of European precipitation, Tellus, 34, 142-150, doi:10.1111/j.2153-3490.1982.tb01801.x, 1982.

Rozanski, K., Froehlich, K., and Mook, W. G.: in Environmental isotopes in the hydrological cycle: Principles and Applications, vol. 3, International Hydrological Programme, United Nations Educational, Scientific and Cultural Organization and International Atomic Energy Agency, Paris, Vienna, 2001.

Schultz, N. M., Griffis, T. J., Lee, X., and Baker, J. M.: Identification and correction of spectral contamination in ${ }^{2} \mathrm{H} /{ }^{1} \mathrm{H}$ and ${ }^{18} \mathrm{O} /{ }^{16} \mathrm{O}$ measured in leaf, stem, and soil water, Rapid Commun. Mass Spectrom., 25, 3360-3368, doi:10.1002/rcm.5236, 2011.

Shuttleworth, W. J. and Wallace, J. S.: Evaporation from sparse crops-an energy combination theory, Q. J. Roy. Meteor. Soc., 111, 839-855, doi:10.1002/qj.49711146910, 1985.

Sklash, M. G.: Environmental isotope studies of storm and snowmelt runoff generation, in Process studies in hillslope hydrology, edited by: Anderson, M. G., 410-435, Wiley, New York, NY, USA, 1990.

Sklash, M. G. and Farvolden, R. N.: The Role Of Groundwater In Storm Runoff, in Developments in Water Science, vol. 12, edited by: Back, W. and Stephenson, D. A., 45-65, Elsevier, Amsterdam, Netherlands., 1979.

Song, X., Wang, P., Yu, J., Liu, X., Liu, J., and Yuan, R.: Relationships between precipitation, soil water and groundwater at Chongling catchment with the typical vegetation cover in the Taihang mountainous region, China, Environ. Earth Sci., 62, 787796, doi:10.1007/s12665-010-0566-7, 2011.

Sprenger, M., Erhardt, M., Riedel, M., and Weiler, M.: Historical tracking of nitrate in contrasting vineyards using water isotopes and nitrate depth profiles, Agric. Ecosyst. Environ., 222, 185192, doi:10.1016/j.agee.2016.02.014, 2016a.

Sprenger, M., Seeger, S., Blume, T., and Weiler, M.: Travel times in the vadose zone: Variability in space and time, Water Resour. Res., doi:10.1002/2015WR018077, 2016b.

Stewart, M. K., Morgenstern, U., and McDonnell, J. J.: Truncation of stream residence time: how the use of stable isotopes has skewed our concept of streamwater age and origin, Hydrol. Process., 24, 1646-1659, doi:10.1002/hyp.7576, 2010.

Stumpp, C. and Hendry, M. J.: Spatial and temporal dynamics of water flow and solute transport in a heterogeneous glacial till: The application of high-resolution profiles of $\delta^{18} \mathrm{O}$ and $\delta^{2} \mathrm{H}$ in pore waters, J. Hydrol., 438-439, 203-214, doi:10.1016/j.jhydrol.2012.03.024, 2012. 
Stumpp, C., Klaus, J., and Stichler, W.: Analysis of long-term stable isotopic composition in German precipitation, J. Hydrol., 517, 351-361, doi:10.1016/j.jhydrol.2014.05.034, 2014.

Tang, K. and Feng, X.: The effect of soil hydrology on the oxygen and hydrogen isotopic compositions of plants' source water, Earth Planet. Sci. Lett., 185, 355-367, 2001.

Taylor, S., Feng, X., Kirchner, J. W., Osterhuber, R., Klaue, B., and Renshaw, C. E.: Isotopic evolution of a seasonal snowpack and its melt, Water Resour. Res., 37, 759-769, doi:10.1029/2000WR900341, 2001.

Thomas, E. M., Lin, H., Duffy, C. J., Sullivan, P. L., Holmes, G. H., Brantley, S. L., and Jin, L.: Spatiotemporal Patterns of Water Stable Isotope Compositions at the Shale Hills Critical Zone Observatory: Linkages to Subsurface Hydrologic Processes, Vadose Zone J., 12, doi:10.2136/vzj2013.01.0029, 2013.

Timbe, E., Windhorst, D., Crespo, P., Frede, H.-G., Feyen, J., and Breuer, L.: Understanding uncertainties when inferring mean transit times of water trough tracer-based lumped-parameter models in Andean tropical montane cloud forest catchments, Hydrol. Earth Syst. Sci., 18, 1503-1523, doi:10.5194/hess-18-15032014, 2014.

van der Velde, Y., Torfs, P. J. J. F., van der Zee, S. E. A. T. M., and Uijlenhoet, R.: Quantifying catchment-scale mixing and its effect on time-varying travel time distributions, Water Resour. Res., 48, W06536, doi:10.1029/2011WR011310, 2012.

Wang, P., Song, X., Han, D., Zhang, Y., and Liu, X.: A study of root water uptake of crops indicated by hydrogen and oxygen stable isotopes: A case in Shanxi Province, China, Agric. Water Manag., 97, 475-482, 2010.

Wang, X. F. and Yakir, D.: Using stable isotopes of water in evapotranspiration studies, Hydrol. Process., 14, 14071421, doi:10.1002/1099-1085(20000615)14:8<1407::AIDHYP992>3.0.CO;2-K, 2000.
Windhorst, D., Waltz, T., Timbe, E., Frede, H.-G., and Breuer, L.: Impact of elevation and weather patterns on the isotopic composition of precipitation in a tropical montane rainforest, Hydrol. Earth Syst. Sci., 17, 409-419, doi:10.5194/hess-17-409-2013, 2013.

Windhorst, D., Kraft, P., Timbe, E., Frede, H.-G., and Breuer, L.: Stable water isotope tracing through hydrological models for disentangling runoff generation processes at the hillslope scale, Hydrol. Earth Syst. Sci., 18, 4113-4127, doi:10.5194/hess-18-41132014, 2014.

Woolfenden, L. R. and Ginn, T. R.: Modeled Ground Water Age Distributions, Ground Water, 47, 547-557, doi:10.1111/j.17456584.2008.00550.x, 2009.

Wu, J., Ding, Y., Ye, B., Yang, Q., Hou, D., and Xue, L.: Stable isotopes in precipitation in Xilin River Basin, northern China and their implications, Chin. Geogr. Sci., 22, 531-540, doi:10.1007/s11769-012-0543-z, 2012.

Xia, Y.: Optimization and uncertainty estimates of WMO regression models for the systematic bias adjustment of NLDAS precipitation in the United States, J. Geophys. Res.-Atmos., 111, D08102, doi:10.1029/2005JD006188, 2006.

Yurtsever, Y.: Worldwide survey of stable isotopes in precipitation, International Atomic Energy Agency, Vienna, Austria, 44 pp., 1975.

Zhao, L., Xiao, H., Zhou, J., Wang, L., Cheng, G., Zhou, M., Yin, L., and McCabe, M. F.: Detailed assessment of isotope ratio infrared spectroscopy and isotope ratio mass spectrometry for the stable isotope analysis of plant and soil waters, Rapid Commun. Mass Spectrom., 25, 3071-3082, doi:10.1002/rcm.5204, 2011. 